\title{
Üniversitenin Markalaşması: Burdur Mehmet Akif Ersoy Üniversitesi’nin Markalaşma Sürecinin İncelenmesi ${ }^{1}$
}

\author{
Celile GÜRBÜZ ${ }^{1 *(D)}$, Özlem ÇETINKAYA BOZKURT ${ }^{2}$ (D), Nil Esra DAL ${ }^{3}$ \\ ${ }^{1} \mathrm{PhD}$. Student, Burdur Mehmet Akif Ersoy University, Social Sciences Institute, Burdur, Turkey, Orcid Id: \\ ${ }^{2}$ Assoc. Prof. Dr., Burdur Mehmet Akif Ersoy University, Bucak Faculty of Business, Burdur, Turkey, Orcid Id: \\ ${ }^{3}$ Asst. Prof. Dr., Burdur Mehmet Akif Ersoy University, Bucak Faculty of Business, Burdur, Turkey, Orcid Id:
}

Geliş Tarihi/Received: 09.02.2020

Kabul Tarihi/Accepted: 04.03.2020
Doi: doi.org/10.31200/makuubd.686923

Araştırma Makalesi/Research Article

\section{ÖZET}

Günümüzde ürün ve hizmetler gibi üniversiteler de marka olma yolunda ilerlemektedirler. Artan rekabet ortamları ve üniversitelerin ulusal ve uluslararası bilinirliğini artırma çabaları üniversitelerin markalaşmasını zorunlu kılmaktadır. Bu çalışmanın amacı Burdur Mehmet Akif Ersoy Üniversitesi’nin marka üniversite olma sürecinde hangi adımları uyguladığını içerik analizi ile incelemek ve üniversitenin marka yönetim sürecine dair değerlendirmelerde ve önerilerde bulunmaktır. Elde edilen verilere göre markalaşma sürecine durum analizi yaparak başlayan üniversite, güçlü ve zayıf yönlerini analiz ederek çalışmalarını sürdürmüştür. Kendini Burdur ilinin can damarında yer alan Mehmet Akif Ersoy Üniversitesi ailesi olarak konumlandıran üniversite, 'İstiklalden İstikbale’ sloganı ile insanların zihninde yer etme çabası ile süreci yönetmektedir. 'Hayvancılık ve Hayvancılığa Dayalı Sanayiciliğin Geliştirilmesi' alanında Kalkınma Bakanlığı tarafından desteklenecek 5 pilot üniversiteden biri olarak seçilen Burdur Mehmet Akif Ersoy Üniversitesi yöre ile ilintili olarak hayvancılık, hayvancılığa dayalı sanayi ve özellikle gıda sanayi konusunda da konumlandırma çalışmaları yapmaktadır.

Anahtar kelimeler: Marka, Marka Üniversite, Marka Yaratma, Marka Kimliği, Markalaşma.

\footnotetext{
${ }^{1}$ Bu çalışma 9-12 Mayıs 2018 tarihinde Burdur' da düzenlenen 7. Türkiye Lisansüstü Çalışmalar Kongresi’ nde sözlü bildiri olarak sunulmuştur.

* Sorumlu yazar/Corresponding author

E-mail/e-ileti: celilegurbuz@gmail.com
} 
Gürbüz, C., Çetinkaya Bozkurt, Ö. \& Dal, N. E.

\title{
Branding of the University: Analysing of Building Brand of Burdur Mehmet Akif Ersoy University
}

\begin{abstract}
Today, universities, like products and services, are on the way to become a brand. Increasing competition environments and efforts to increase the national and international awareness of universities require the branding of universities. The aim of this study is to analyze what steps Burdur Mehmet Akif Ersoy University has followed in the process of becoming a brand university with content analysis and to make evaluations and suggestions regarding the brand management process of the university. According to the data obtained, the university started its branding process by analyzing the situation and continued its studies by analyzing its strengths and weaknesses. Positioning itself as the family of Mehmet Akif Ersoy University, located in the heart of the province of Burdur, the university manages the process with the effort of being in the minds of people with the slogan ' From Independence to Independence''. Burdur Mehmet Akif Ersoy University, which is selected as one of the 5 pilot universities to be supported by the Ministry of Development in the field of " Development of Livestock and Livestock-Based Industrialism', also conducts positioning studies in the field of animal husbandry, animal husbandry-based industry and especially food industry.
\end{abstract}

Keywords: Brand, Brand University, Brand Creation, Brand Identity, Branding.

\section{GIRİŞ}

Üniversiteler günümüzde ihtiyaç duyulan ileri düzeydeki yüksek nitelikli insan gücünü eğiten, gelecekteki hedefleri doğrultusunda bilimsel araştırmalar yapan kurumlardır. Toplumla bütünleşmeyi sağlayacak projeler üretip geliştirirler. Toplumun beklentilerine cevap vererek onların ilerlemelerine ve gelişmelerine katkıda bulunurlar (Çağlayandereli ve Güleş, 2013: 2).

Son y1llarda öğrencilerin yurt içi ve yurt dışındaki üniversite tercih seçeneklerinin artması, üniversiteler arası rekabeti de beraberinde getirmiştir. Öğrenciler üniversitenin sahip olduğu özellikleri tek tek incelemek yerine üniversite kalitesini belirleyen birçok özelliği bünyesinde barındıran üniversite markasına bakmayı yeterli görmektedir (Torlak ve Doğan, 2011: 98). Birçok hizmet sektöründeki organizasyonlarda olduğu gibi üniversiteler de rekabetçi ortamın artmasıyla kendilerini diğerlerinden farklılaştırması gerektiği gerçeğiyle yüz yüze gelmişlerdir. Bu nedenle üniversiteler kendilerini çevrelerine daha iyi anlatma gayreti içerisine girmektedirler (Judson vd., 2008: 57). Güçlü bir marka, hizmet edilen hedef kitlenin verilen 
hizmetten memnun olarak ayrılmasını sağlar. Üniversitelerin marka olma yolundaki faaliyetleri sonucunda nitelikli öğretim elemanlarını ve başarılı öğrencileri bünyesine katabilmekte ve hedef kitlesi olan halka doğru ulaşabilmek için pazarlama faaliyetlerini gerçekleştirmektedirler.

Alan yazında markalaşma üzerine pek çok çalışma yer almasına rağmen, üniversitelerin markalaşması konusunda pek fazla çalışmaya rastlanmamıştır. Bu çalışma ile üniversitelerin markalaşma sürecinin nasıl işlediği konusunda alan yazına katkı sağlanması düşünülmektedir. Buradan hareketle; çalışmanın temel amacı, Mehmet Akif Ersoy Üniversitesi'nin marka üniversite olma sürecinde hangi aşamada olduklarını içerik analizi ile incelemek ve elde edilen bulgular sonucunda üniversitenin markalaşma sürecine dair önerilerde bulunmaktır.

\section{MARKA VE MARKALAŞMA İLE İLGİII KAVRAMLAR}

\subsection{Marka Kavramı ve Marka Üniversite}

İşletmeler yaşanan yoğun rekabet ortamında varlıklarını devam ettirme ve büyüme sağlamak için sürekli yeni strateji ve yöntem arayışı içerisindedirler. Bu arayışlardan biri son yıllarda önemini artıran marka kavramıdır. Amerikan Pazarlama Birliği'ne (AMA) göre; marka; "bir satıcının mal ve hizmetlerini diğer satıcılarınkinden ayırarak betimleyen isim, terim, tasarım, sembol ya da diğer özelliklerdir". Daha kapsamlı bir tanımla marka kavramı; "bir kişinin (tüketicinin) ürünü, hizmeti, tecrübeyi, organizasyonu veya marka inşası sanatını algılaması, fark etmesi, kavraması" olarak açıklanabilir (Okur, 2007: 32). Bu tanımlara göre işletmeler markaları ile rakiplerine üstünlük sağlamakta, ürün ya da hizmetlerinde farklı ve özgün olabilmektedirler. Markalar tüketicilere büyük bir değer sunar ve işletme ile tüketici arasında ilişki kurar. Müşterileri ile güçlü ilişki kurabilen markalar; ayırt etme, tercih oluşturma ve prestij sağlama yetisine sahiptir (Çifci ve Cop, 2007: 70). Markalar, mesajlarını tüketicilere iletirken aslında onlara söz ve vaat taşımaktadırlar. Tüketiciye sunulan ürün ya da hizmetle ilgili güçlü çağrışımlar yaratan, ürün ya da hizmetin özelliklerini, tüketiciye yararını, organizasyon değerlerini, kişilik özelliklerini ve hedef kitleyi odaklayan bir vaadi içermektedir. Ayrıca tüketicinin ürün ya da hizmeti deneyimlemesinin ardından kendisini nasıl hissedeceğine dair sözleri de içermektedir (Okur, 2007: 47).

Bir isim, tasarım ya da hizmet marka olarak adlandırılabileceği gibi bir organizasyon veya edinilen tecrübeler de marka olarak kabul edilebilir. Sivil toplum örgütlerinin marka olarak tanımlanmasını (AFAD, AKUT vb.) veya yükseköğretim hizmetlerini pazarlayan bir 
üniversitenin marka olarak algılanmasını (HARVARD, ODTÜ vb.) bu duruma örnek olarak verilebilir (Okur, 2007: 32).

Üniversite markası, kurumun özelliklerini başkalarından ayıran, öğrencilerin ihtiyaçlarını karşılama kapasitesini yansıtan, belirli bir tür ve yükseköğrenim seviyesi sunma gücüne olan güvenini kazandıran ve potansiyel yeni başlayacak olanlara kayıt esnasında yardım eden kurum özelliklerinin bir tezahürü olarak tanımlanmaktadır (Ali-Choudhury vd., 2009: 14). Diğer bir ifade ile üniversite markasına bakıldığında onun rakiplerinden farklı olan yönlerini, ihtiyaçlarını karşılamak üzere öğrencilere ne tür vaatlerde bulunduğunu, eğitim kalitesini ve üniversitenin sahip olduğu özellikleri hakkında çıkarım yapılabilir. Üniversitelerin markalaşma nedenlerine bakıldığında temel nedenin marka yardımıyla hedef kitle olan öğrencilerin ve onların ailelerinin, nitelikli öğretim elemanlarının, işveren kuruluşların dikkatini çekerek onlarla iletişim kurulması olduğu söylenebilir (Nardalı ve Tanyeri, 2011: 311).

Yoğunlaşan rekabet, akademide markalaşmanın önemini artırmıştır. Örneğin üniversiteler, öğrenci sayısını ve kalitesini arttırmayı, öğrenci sadakatini iyileştirmeyi, mezun bağlantılarını iyileştirmeyi, yetenekli çalışanları işe almayı ve kurumsal sektörden destek almanın yanı sıra kendilerini yükseköğretimdeki diğer aktörlerden daha fazla ayırt eder. Bununla birlikte, yüksek öğrenimin paydaş ortamına göre belirgin şekilde çok yönlü olduğu ve bu nedenle diğer birçok ortamdan farklı olduğu iddia edilmektedir (Clark vd.; 2019: 4).

Üniversitelerin marka oluşturma süreci kentlerin marka oluşturma süreci gibi düşünebilir. Kentlerin rekabet avantajı sağlaması için marka oluşturması gerektiği gibi üniversitelerin de rekabet avantajı sağlaması ve bilinirliğini artırması için marka üniversite olma yoluna gitmesi gerekmektedir. Güçlü bir marka imajına ve kimliğine sahip olmak, piyasadaki konumunu belirleyerek, onları rekabetten korumak ve pazar performansını iyileştirmek yoluyla üniversitenin yararına olabilir (Watkins ve Gonzenbach, 2013: 20).

Üniversiteler, tanıtım çabalarını güçlendirmek için entegre pazarlama tekniklerini giderek daha fazla uygulamaya başlamıştır (Wasmer vd., 1997: 31). Judson vd.ne göre (2008: 57) koordine edilmiş, müşteri odaklı bir pazarlama sistemine yönelik kurumsal çabaların bir parçası olarak, üniversiteler ayrıca üniversite markasını geliştirme üzerine odaklanmalıdırlar. Marka bilinci oluşturma, “örgütün kimliğinin niteliklerini, açıkça tanımlanmış bir marka önerisi şeklinde duyurmak" anlamına gelmektedir (Balmer, 2001: 281). Bunu yapabilmek için kuruluşun kendisi için öncelikle "ne" ve "kim” in özünü, değerler ve özellikler açısından "neyi" temsil ettiğini tanımlaması gerekir. Bu tanımın olabildiğince kesin ve tutarlı olması ve oldukça 
tutarlı bir biçimde iletilmesi gerekmektedir. Ayrıca, sadece üst yönetimin marka özünü bilmesi yeterli değildir; tüm çalışanlar bir anlamda marka yöneticisi olmalı ve tercihen "markayı yaşamalıdır" (Waeraas ve Solbaak; 2009: 1-2). Taş ve Ergin (2012: 147) üniversitelerin sayısının ve yükseköğrenime yönelik genç nüfusun büyüklüğünün göz önünde bulundurulmasını, üniversite marka bilinci oluşturma konusunda daha fazla araştırma çalışmalarına önem verilmesi gerektiğini belirtmişlerdir.

Günümüzde birçok üniversite marka üniversite olma çabası içine girmiştir. Üniversiteler; amacı, kimliği ve kalitesi belirsiz markayı tutundurmak maksadıyla yüksek bütçeli yatırımlar yapmasına rağmen yapılan yatırımların etkinliğine ve sonuca yönelik kamuya açık araştırmalara rastlanmamıştır (Başer, 2008: 105). Bu tür değerlendirmelerin yapılması üniversitelerin markalaşmada hangi düzeyde olduklarını gösterecek ve sonraki adımlar için referans sağlayacaktır.

\section{2. Üniversitenin Marka Kişiliği ve Marka İmajı}

Güçlü ve başarılı marka yaratma ve bu markaları tüketicinin zihninde konumlandırma aşamasında ürünün dışsal özellikleri artık yeterli gelmemeye başlamıştır. Bu noktadan hareketle markaların da insanlar gibi farklı olabilmesi için bir kişiliğe sahip olması gerektiği düşünülmüş ve insana ait özellikler markalara aktarılmıştır (Aysen vd., 2012: 184). Marka kişiliği, insana ait birçok özelliğin markaya yüklenmesidir. İnsani unsurlar olan güven verme, önemseme, heyecan verici olma, ilham verici olma, yenilik getirme, daha iyi bir yaşam sunma, eğlence veya iş yapmaya yönelik zevk verme gibi temel değerleri içeren bir kavramdır (Ar, 2002: 69). Marka kişiliğinin insan kişiliğinden farklı olan yönü, genellikle pazarlama iletişimcileri tarafından pazarlama karmasından faydalanılarak planlı ve bilinçli çalışmalar yürütülmesiyle oluşturulmasıdır (Aaker, 1997: 347). Aaker (1997: 352) bireyin kişiliğinden yola çıkarak geliştirmiş olduğu marka kişiliği ölçeğinde marka kişiliğini niteleyen özellikleri beş boyutta ele almıştır. Bu boyutlar "samimiyet”, “coşku”, "ustalık”, "seçkinlik” ve "sertliktir”.

Bir markanın kişiliği hakkındaki ilk bilgiler; markanın isminden, renginden, hangi harflerle yazıldığından, logosundan ve ambleminden elde edilir. Tüketiciler bir markayla buluştuklarında o markayla ilgili bir deneyim yaşar ve o markanın kişiliği hakkında bilgi edinirler. Kişiliksiz markalar ise, insanlara güven vermez (Aksoy, 2015: 46).

Tüketiciler marka kişiliği ile ürün arasında kurdukları ilişkide; kendi kişilikleri ile marka kişiliği arasında ortak nokta yakaladıklarında o marka, tüketicinin zihninde farklı bir boyut 
kazanmaktadır. $\mathrm{Bu}$ sebeple işletmeler markanın tüketiciler tarafından daha rahat benimsenmesini sağlamak için uyguladıkları stratejilerde marka kişiliğine önem vermektedirler (Aysen vd., 2012: 184). Marka kişiliğinin doğru belirlenerek tüketicilerle ürün arasında duygusal bağ oluşturulması markanın etkililiğinin artmasını olumlu yönde destekleyecektir. Torlak ve Doğan (2011: 110) çalışmalarında ODTÜ ve Boğaziçi üniversitelerinin tüm marka algısı boyutları bakımından ortalamanın üzerinde olduğunu tespit etmişlerdir. ODTÜ uluslararası düzeyde öncü, bölgeyi ve dünyayı dönüştüren üniversite olma vizyonuyla markalama çalışmalarını sürdürmektedir. Dünyanın en iyi üniversitelerinden biri olarak görülen Harvard Üniversitesi eşsiz marka imajı ve marka vaadi olmasına rağmen yükseköğrenim pazarındaki yerini sağlamlaştırabilmek adına büyük çaba sarf etmektedir. İlk kez bir nesilde müfredatını yenileyen üniversite daha çok küresel perspektife odaklanmaktadır. Akademik tekliflerini değişen dünyayı yansıtacak şekilde güncelleyen üniversite, ortak misyon duygusu ile katılımcı bir duygu oluşturmaya çalışmaktadır (Lockwood ve Hadd, 2007: 6).

Marka kişiliği ile marka imajı birbirinden ayrı düşünülmeyen kavramlardır (Aysen vd., 2012: 185). Marka imaj1; tüketicinin ürün ya da hizmetle ilgili duygu, düşünce ve beklentileridir (Yıldız, 2015: 20). Marka imajı kavramı içerisinde gerçek tecrübeler, diğer müşterilerden alınan geribildirimler, marka ismi, ambalajı, dağıtım şekli, nerede satıldığı, reklamlarındaki ton ve biçimler, kullanılan medya, markayı kullanan, satın alan veya tavsiye eden insanların özellikleri yer almaktadır (Okur, 2007: 40).

Tüketiciler bilinçli olarak bir markayı tercih edebilirler ve bu şekilde zihinlerinde marka imajı oluşur. Tüketicilerin kendi kişiliğine benzer bir marka satın alma ihtimali yüksektir. Etkili bir marka, belirli bir tüketici grubu tarafından tutulur ve kendisine atfedilen kişilik özelliklerini korur ise kendi marka değerini arttırır. Markalar tüketiciler için bir seçim sağlar ve tüketici davranışlarını ortaya çıkarmak için onlara yol açar (Tayfur vd., 2016: 244).

Kâr amaçsız organizasyonlarda marka imajı, daha çok üretilen mal veya hizmete yapılan vurgu ve reklamın etkisi ile oluşur. Marka kişiliği ise sunulan ürün veya hizmetlerin etkinliği, sosyal fayda yoğunluğu, sürekliliği, ürün veya hizmetten faydalanan veya pazarlanmasında rol alan bireylerin sosyal ve manevi tatmini, izlenen pazarlama stratejileri ve geribildirimleri sonucu oluşur (Okur, 2007: 41). Son yıllarda üniversite imajının çeşitli yönlerini inceleyen birçok çalışma yapılmıştır. Bu çalışmalarda kurumların imaj oluşturma, tanıtım ve pazardaki imajlarını farklılaştırmak için pazarlamayı nasıl kullandıkları; kurumsal imajın üniversite 
seçimini nasıl etkilediği, kurumsal imajın öğrenci memnuniyeti üzerindeki etkisi, sadakat ve genel olarak destekleyici davranışlar incelenmiştir (Wilkins ve Huisman, 2013: 3).

Marka üniversite olma sürecinde üniversitenin imaj1 önemli noktalardan biridir. Sunulan hizmetin vurgulanması ve izlenecek etkin iletişim stratejileri ile hedef kitle üzerinde oluşturulacak olumlu imaj; üniversitenin rekabetini artıracak, kalıcı ve güçlü bir marka oluşturacaktır. Ekonomik alanda bir ticari marka imajının insanların satın alma davranışını etkilemesi gibi üniversitelerin imajı da öğrencilerin ve akademik personelin o üniversiteyi tercih etmesini etkilemektedir. Üniversite öğrencilerinin aldığı hizmetlerle ilgili tatmini ve değerlendirmeleri, üstün bir marka imajına sahip olan ilgili kurumun marka kişiliğini doğrudan etkileyecektir (Okur, 2007: 41).

\section{3. Üniversitenin Marka Adının Belirlenmesi}

Ürün ya da hizmetlerin markalaşması sürecindeki önemli adımlardan biri marka isminin belirlenmesidir. Başarılı bir isim seçimi markaya güç katmakta, markanın pazarda tutunmasına yardımcı olmakta, hedef kitle ile duygusal bir bağ kurulmasına katkı sağlamaktadır. Seçilecek isim markanın konumlandırma stratejileri ile uyumlu olmalıdır. Marka ismini güçlü ve başarılı kılmak için sağlam marka stratejileri uygulanmalıdır. İsim belirlenirken rakiplerin isimleri de incelenmeli, farklılaşma noktaları belirlendikten sonra isim çalışmasına başlanmalıdır. Marka ismi hedef kitleye de hitap etmelidir (Borça, 2013: 109).

Üniversitelerin isminin belirlenmesi, üniversite adına son derece özel bir konuma sahiptir (Nardalı ve Tanyeri, 2011: 314). Üniversitelerin ismi genelde bulunduğu il ve çevrede tanınan, bölgeye katkısı bulunan, kahramanlığıyla gönüllere taht kurmuş kişilerin isimlerinden ya da yöreye özgü isimlerden oluşmaktadır. Örneğin Abdullah Gül Üniversitesi, Adnan Menderes Üniversitesi ismini yörede tanınan ünlü siyasetçilerden; Alanya Alaaddin Keykubat Üniversitesi, Ankara Yıldırım Beyazıt Üniversitesi ismini tarihi kişilerden ve Akdeniz Üniversitesi, Avrasya Üniversitesi ismini bulunduğu yöreden almaktadır. Mehmet Akif Ersoy Üniversitesi adını ünlü şairimiz Mehmet Akif Ersoy’ dan almaktadır. Mehmet Akif Ersoy; Birinci Türkiye Büyük Millet Meclisinde Burdur Mebusu olarak görev yapan, Burdur ilinin önem verdiği, benimsediği bir şahsiyettir. Şaire verilen önem ve İstiklal Marşı’ mızın yazarı olması vesilesiyle üniversiteye onun adı verilmiştir. Özel üniversitelere bakıldığında genellikle kurucu vakıfların isminin verildiği görülmektedir. Örneğin; Koç Üniversitesi, Sabancı Üniversitesi, Türk Hava Kurumu Üniversitesi. Ayrıca özel üniversitelere bulunduğu yerlerin isimleri de verilmektedir. Örneğin; İzmir Tınaztepe Üniversitesi, Yakın Doğu Üniversitesi. 


\section{3. ÜNIVERSITTENIN MARKALAŞMA STRATEJILERI}

Marka yönetim süreci markalaşma stratejilerinin belirlenmesi, uygulanması ve uygulama sonucunda elde edilen verilerin incelenmesi ile anlam kazanmaktadır. Aaker'ın (1996) stratejik marka analizine göre, marka stratejileri belirlenirken yapılması gereken ilk adım durum analizidir. İşletmelerin ürün ya da hizmetlerini markalarken müşteri analizi, rekabet analizi ve kişisel analiz yapmaları gerekmektedir. Markanın tüketici tarafından nasıl algılandığ 1 , müşterilerin istek ve ihtiyaçlarının neler olduğu tespit edilerek hedef pazar seçilmelidir. Aynı zamanda rakiplerin de dikkatli bir şekilde analiz edilmesi gerekmektedir. Rakiplerin de hangi kimliğe sahip olduğu, imajı ve ne tür konumlandırma yaptıkları incelenmelidir. Onların da güçlü ve zayıf tarafları analiz edilmelidir. Son olarak kişisel durum analizini yaptıktan sonra mevcut veriler göz önünde bulundurularak stratejiler belirlenmelidir (Çifci ve Cop, 2007: 71).

Üniversitelerin markalaşma süreci de benzer şekilde işlemektedir. Üniversite yönetimi öncelikle 'markalama' kararı vermelidir. Üniversitenin marka olarak konumlandırılması ve bunun sebatkar şekilde sürdürülmesinde marka olmaya karar veren, güçlü ve vizyon sahibi paydaşlardan oluşan bir komisyon kurulması bu sürecin yapı taşıdır. Komisyon kurulmasının ardından markalama stratejilerine karar verilmesi gerekmektedir. Bu aşamada yapılması gereken ilk işlem durum analizidir. Üniversitelerin hizmetlerini markalarken hedef kitle, rakip ve marka analizi yapmaları gerekmektedir. Markanın hedef kitle tarafından nasıl algılandığı, hedef kitlenin istek ve ihtiyaçlarının neler olduğu tespit edilerek hedef pazar seçilmelidir. Aynı zamanda rakiplerin de dikkatli bir şekilde analiz edilmesi gerekmektedir. Rakiplerin de hangi kimliğe sahip olduğunu, imajını ve ne tür konumlandırma yaptıkları incelenmelidir. Onların da güçlü ve zayıf tarafları analiz edilmelidir. Üniversite markası analizinde de üniversitenin marka kişiliği, marka imajı, üstün ve farklı yönleri analiz edilmelidir.

Üniversitelerin hedef pazarını oluşturan öğrencilerin üniversite seçimini \%95 oranda hayallerindeki üniversiteyi okumak istemeleri etkilidir (Coşar, 2016: 5). Paydaşlar üniversite marka algısını oluştururken mezuniyet sonrası beklentileri, öğrenme çevresini ve sosyal çevreden oluşan vaatleri en fazla önemsemektedirler. Sembol ve tanıtım boyutu ikinci sırada yer almakta ve bu boyut üniversite ismi ve logosu ile pazarlama iletişim çabalarından oluşmaktadır (Torlak ve Doğan, 2011: 109). Ayrıca potansiyel öğrenciler karar alırken yükseköğretim kurumu tarafından sunulan eğitimin kalitesi ve kurum hakkındaki sosyal 
çevreden edinilen bilgileri göz önünde bulundurarak üniversiteyi tercih etmektedir (Ekici, 2012: 164).

\section{1. Üniversitenin Marka Kimliği}

Marka kimliği, insanların zihinlerinde markaya yönelik ilişki kurdukları her şeyi ifade eder. Yani müşterilerin markayı nasıl algıladıklarının özüdür. İşletmeler güçlü bir marka kimliği yaratarak farklılaşır, müşteriye satın almak için neden sunar, onlara güven verir, tüketicinin ürüne karşı hislerini etkiler ve pazarda güçlü bir konumlandırma sağlar (Çifci ve Cop, 2007: 72).

Marka kimliği, markanın ne yapmak istediğini açıkça belirtir. Marka stratejistinin yaratmaya ve sürdürmeye çalıştı̆̆ı bir dizi özellikler bütünüdür. Belirli bir markanın hedef kitle tarafından nasıl algılandığının vizyonunu temsil eder. Marka kimliğgi; markanın potansiyel faydalarını içeren ya da ilgili markayı destekleyen, güvenilirliğini temin eden bir değer üreterek marka ile müşteri arasında ilişki kurmaya olanak sağlar (Hassan vd., 2010: 274).

Aaker (1996: 68) kapsamlı bir marka kimlik planlaması geliştirmiştir. Bu modelin merkezinde marka kavramında dört katlı bir perspektif vardır. Bir firmanın marka kimliğine sahip olmasını sağlamak için markayı bir ürün, bir organizasyon, kişi ve bir sembol olarak düşünmesi gerekmektedir. Bunların dışında fonksiyonel, duygusal ve ifadesel faydaları içeren değer önermeleri oluşturularak marka ile tüketici arasında etkileşim sağlanmalıdır. Fonksiyonel ihtiyaçlar; tüketicilerin kullanım ile ilgili problemlerinden kaynaklanan, duygusal ihtiyaçlar; duyu organlarına yönelik zevklerden ortaya çıkan ihtiyaçlardır. İfadesel ihtiyaçlar ise kendini geliştirme, grup veya sınıf üyeliği vb. psikolojik ihtiyaçlardır (Şahin, 1998: 238).

Marka kimliğini oluştururken kullanılacak araçlar; marka adının tüketicinin zihninde çağrıştırması gereken olumlu sözcük, doğru, etkileyici ve tekrarlanabilir bir slogan, tutarlı bir renk grubu, iletişimi sağlayacak semboller ve logolar, olumlu ve ilginç bir yarar oluşturacak bir dizi öyküdür (Kotler, 2000: 92). Logo, markanın görsel sembolü olan bir amblem ile markanın isminin ayırt edici biçimde bir araya gelmesiyle oluşur (Torlak, 2015: 72). Sözcük olmayan işaret logolarına da genellikle semboller denir. Araştırmalara göre logo sadece tipografik öğelerden oluşabileceği gibi sembol içerikli de olabilmektedir. Başarılı bir logo özgün olmalıdır, basit ve anlaşılır olmalı, olumlu bir etki oluşturmalı ve sektöre uygun renklerle oluşturulmalıdır (Özer, 2015: 12). 
Tablo 1. Marka kimliği planlama modeli

\begin{tabular}{|c|c|c|c|c|c|}
\hline \multicolumn{3}{|c|}{ Müşteri Analizi } & \multicolumn{2}{|l|}{ Rekabet Analizi } & Kişisel Analiz \\
\hline \multicolumn{3}{|c|}{$\begin{array}{l}\text { *Motivasyonu } \\
\text { *İstek ve ihtiyaçları } \\
\text { *Pazar bölümlendirme }\end{array}$} & \multicolumn{2}{|c|}{$\begin{array}{l}\text { *Marka imajı/ kimliği } \\
\text { *Güçlü ve zayıf yönleri } \\
\text { *Marka stratejileri }\end{array}$} & $\begin{array}{l}\text { *Güçlü ve } \\
\text { zayıf yönleri } \\
\text { *İşletmenin } \\
\text { değeri }\end{array}$ \\
\hline \multicolumn{6}{|c|}{ Marka Kimliği } \\
\hline \multicolumn{2}{|l|}{$\begin{array}{l}\text { Ürün olarak } \\
\text { marka }\end{array}$} & \multicolumn{2}{|c|}{$\begin{array}{l}\text { Organizasyon olarak } \\
\text { marka }\end{array}$} & $\begin{array}{l}\text { Kişi olarak } \\
\text { marka }\end{array}$ & $\begin{array}{l}\text { Sembol } \\
\text { olarak marka }\end{array}$ \\
\hline \multicolumn{2}{|c|}{$\begin{array}{l}\text { *Ürün kapsamı } \\
\text { *Ürün katkıları } \\
\text { *Kalite/ Değer } \\
\text { *Kullanım } \\
\text { *Kullanıcılar } \\
\text { *Ülke/ Menşei }\end{array}$} & \multicolumn{2}{|c|}{$\begin{array}{l}\text { *Organizasyon katkıları } \\
\text { (Yenilik, müşteri ilgisi, } \\
\text { güvenirlik) } \\
\text { *Yerel ya da küresel } \\
\text { faaliyet alanı }\end{array}$} & $\begin{array}{l}\text { *Kişilik (dürüst, } \\
\text { enerjik) } \\
\text { *Müşteri- marka } \\
\text { ilişkisi (Arkadaş, } \\
\text { tavsiyeci) }\end{array}$ & $\begin{array}{l}\text { *Görsel } \\
\text { simgeler }\end{array}$ \\
\hline \multicolumn{4}{|c|}{ Değer Önerileri } & & Güvenirlilik \\
\hline $\begin{array}{l}\text { Fonksiyonel } \\
\text { faydalar }\end{array}$ & \multicolumn{2}{|c|}{$\begin{array}{l}\text { Duygusal } \\
\text { faydalar }\end{array}$} & İfadesel faydalar & & $\begin{array}{l}\text { *Diğer } \\
\text { markaları } \\
\text { desteklemek }\end{array}$ \\
\hline \multicolumn{6}{|c|}{ Marka- Müşteri İlişkisi } \\
\hline \multicolumn{6}{|c|}{ Marka Kimliği Yerleştirme Sistemi } \\
\hline \multicolumn{6}{|c|}{ Marka Konumlandırma } \\
\hline \multicolumn{6}{|c|}{ Uygulama } \\
\hline
\end{tabular}

Kaynak: Aaker, D. A. (1996). Building strong brands. New York: Free Press.

Sloganlar tekrarlanarak insanların zihninde yer eden sözlerdir. Sloganların eğlenceli, dikkat çekici, merak uyandırıcı ve anlamlı olması hedef kitlenin sloganları keyifli bir şekilde hatırlamasını sağlayacaktır (Torlak, 2015: 72).

Bir kuruluşu, ürünü, markayı temsil eden çizgi ve resimle yapılan soyut ya da nesnel simgelere amblem denir. Amblemin görsel ifadelerden oluşturulması, okuma yazma bilmeyen kişilerin de markayı algılamalarını kolaylaştıracaktır (Özer, 2015: 12). Üniversiteler logo ve amblemlerini kimi zaman profesyonel kişilere tasarlatmakta kimi zaman ise kamuya açık bir yarışmayla (Recep Tayyip Erdoğan Üniversitesi) kimi zaman ise senato kararı ile (Karadeniz Teknik Üniversitesi) belirlemektedir. Tasarımcılar bu konuda daha çok üniversitenin bulunduğu şehrin tarihi ve kültürel unsurlarından yararlanarak logo ve amblemleri tasarlamaktadırlar (Çakır, 2013: 54).

Üniversite kimliği, bir öğrencinin yükseköğretim ile olan bağlılığına veya aidiyetine atıfta bulunan belirli bir sosyal kimlik biçimidir (Wilkins ve Huisman, 2013: 7). Üniversiteler; rakiplerinden farklılaşmak, hedef kitle tarafından olumlu algılanmak ve pazarda güçlü konumlandırma sağlamak için marka kimliğini oluşturmalıdır. Hedef kitleye sunulan fiziki altyap1, verilen hizmetlerin personel tarafından sunum tarzı, üniversitenin tüm paydaşların 
zihnindeki yer, güçlü bir logo, etkileyici ve tekrarlanabilen slogan, üniversiteyi tarif eden bir marka adı, marka kimliğini oluştururken kullanılacak araçlardır (Okur, 2007: 42).

\subsection{Konumlandırma ve Üniversitenin Marka Konumlandırması}

İşletmeler başarılı ve güçlü marka yaratmak için öncelikle markalarını farklılaştırma yoluna giderler. Marka farkındalığının sağlanmasının ardından tüketicinin ürünü hangi kişilik ve kimlik ögeleriyle hatırlayacağını belirleyen unsur marka konumlandırmasıdır. Marka konumlandırma, marka kimliği ögeleri ile uyumlu bir şekilde farklılaştırıcı bir değerin tüketicilerde yaratılma çabasıdır (Borça, 2013: 84). Ürünün ya da hizmetin konumlandırılması; insanların zihninde daha iyi bir imaj sağladığı için konumlandırma marka yönetiminin merkezi ve önemli bir unsurudur. İyi bir marka konumlandırma; bir markanın neyle alakalı olduğunu, onun benzersiz olan ve rekabetçi markalara benzeyen yönlerini, tüketicilerin neden markayı satın alıp kullanması gerektiğini netleştirerek pazarlama stratejisine rehberlik etmeye yardımcı olur (Keller, 2013: 79).

Hizmet sektörü içerisinde yer alan üniversiteler, güçlü oldukları yönlerini ön plana çıkararak marka olma yolunda ilerlemelidirler. Bu bağlamda yapılacak önemli işlemlerden biri konumlandırma çalışmalarıdır.

Gray vd. (2003: 117) Asya pazarı için yaptıkları araştırmalarında; üniversitelerin konumlandırılması aşamasında aşağıda verilen 5 temel marka konumlandırılması faktörlerine dikkat edilmesi gerektiğini belirtmiştir:

Üniversitenin eğitim çevresi: Üniversitenin sahip olduğu nitelikli öğretim elemanları, fiziki şartların yeterli olması ve araştırmalara ayrılan kaynaklardır.

İtibar: Üniversitenin marka ismi, üniversitenin gerçekleştirdiği başarılar ve yüksek eğitim standartları ve eğitimin kaliteli oluşudur.

Mezunların kariyer olanakları: Mezun olan öğrencilerin istihdam olanakları, elde edebilecekleri tahmini gelir ve işverenlerin ilgili mezunlara bakışıdır.

Bölgesel imaj: Ülkenin istikrarlı politik yapısı, ülkedeki güvenlik, yerel halkın misafirperverliğidir.

Kültürel uyum: Dini özgürlükler ve farklı kültürlere bakıştır. 
Potansiyel öğrencilerin ve velilerinin, üniversitenin ne anlama geldiğini anladıkları zaman üniversitenin etkin bir şekilde konumlandırıldığı söylenebilir. Ayrıca kabul için üniversiteye başvuran öğrenci sayısının artışı da konumlandırmanın başarısını gösterir. Öğrenci pazarının ihtiyaçlarını karşılamak üzere okullar konumlandırıldıkça başarısız öğrenci sayısı da azalmaya başlayacaktır (Lowry ve Owens, 2001: 30).

Türkiye' deki üniversitelere bakıldığında öğrenciler tarafından en çok hayal edilen üniversite olan (Başer, 2008: 164) Boğaziçi Üniversitesi nitelikli eğitim ile konumlandırma çalışmalarını gerçekleştirmektedir. Eğitim, öğretim ve araştırmada öncü konumuyla geleceği şekillendiren üniversite olma vizyonuyla çalışmalarını sürdürmektedir. ÖSYS' de en çok tercih edilen ikinci devlet üniversitesi olan İstanbul Üniversitesi (Başer, 2008: 159) mezunların kariyer olanaklarına odaklı konumlandırma çalışması gerçekleştirmektedir. Öğrencilerin gerçek potansiyellerini ortaya çıkarmayı hedeflemekte, karşılaştıkları sorunlara çözüm önerisi sunabilen öğrenciler yetiştirebilmeyi hedeflemektedir.

Çatı vd. (2016) üniversitelerin tanıtım videosunu analiz ederek gerçekleştirdikleri çalışmalarında tanıtım videosuna erişebildikleri 90 üniversiteden 49' unun kendilerini eğitim alanlarında konumlandırdıklarını belirtmişlerdir. Bu eğitim alanlarından özellikle sağlık, mühendislik ve iktisadi ve idari bilimler ön plana çıkmaktadır.

Dünyanın en iyi üniversiteleri arasında kabul edilen Harvard Üniversitesi markasını itibar faktörü ile konumlandırmaktadır. Öğretmeye hevesli ve insan bilgisinin sınırlarını zorlamaya yönelik araştırmaların yapıldığı üniversite, araştırmaya hevesli olan öğrencilere benzersiz bir deneyim sunmakta ve öğrencilere cömert bir maddi destek sağlamaktadır.

\section{4. ÜNIVERSITELERIN MARKALAŞMASI ÜZERINE YAPILAN ÇALIŞMALAR}

İlgili alan yazında markalaşma sürecine ilişkin pek çok çalışma olmasına rağmen üniversitelerin markalaşması ile ilgili yapılan fazla araştırmaya rastlanmamıştır. Örneğin; Nardalı ve Tanyeri (2011: 309) çalışmalarında üniversitede markalaşma ile ilgili literatür taraması yaparak üniversitelerin markalaşma nedenleri, markalaşma aşamasında yaşanan sorunları tespit ederek markalaşma bağlamında üniversite yöneticilerine önerilerde bulunmuşlardır. Torlak ve Doğan (2011: 97) üniversite adaylarının üniversite marka algılarının üniversite tercihlerine etkilerini ölçtükleri çalışmalarında genel olarak marka algılarının üniversite adayı öğrencilerin üniversite tercihlerine yansıdığını tespit etmişlerdir. Taş ve Ergin (2012: 146) ise; öğrencilerin ABD'de bir üniversitede yüksek lisans programını araştırırken 
önemli olduklarını düşündükleri kriterleri belirlemek ve keşfetmek amacıyla yaptıkları çalışmalarında öğrencilerin tercihini etkileyen birçok faktör olduğunu, yüksek eğitim standartları ve mezuniyet sonrası iş ve kariyer hizmetleri kriterlerinin öğrenciler arasında benimsendiğini belirtmiştir.

Chapleo (2010: 169) üniversite marka etkinliği ile ilgili sorunları belirlemek amacıyla yaptığı çalışmasında başarılı markalara sahip olduğu düşünülen üniversitelerin ortak özelliklerini araştırmıştır. Judson vd. (2009: 64) yükseköğretimde düzenli olarak üniversite markası vaadini dış seçim bölgelerine iletme fırsatı bulan yöneticiler üzerinde yaptıkları çalışmalarında sadece entegre pazarlama çabalarını kucaklayan bir endüstri içinde yükseköğretim markasının içsel tanıtımını araştırmışlardır. Çalışmada üniversitenin marka imajının, üniversite yöneticilerinin iş fonksiyonlarını yerine getirmeleri biçimine nispeten güçlü bir etkiye sahiptir. Ayrıca üniversite broşürlerinin, marka mesajının iç izleyicilere ulaştırılmasında kullanılan en yaygın ve en etkili medya olduğunu belirtmişlerdir.

Gray vd. (2003: 108) Asya pazarındaki üniversite markalaşmasını inceledikleri çalışmalarında üniversite hakkındaki bilgilere ulaşmada yazılı medyanın ve internetin en önemli kaynaklar olduğunu belirtmiş, üniversitelerin marka konumlandırmasında dikkat etmesi gereken faktörlerin neler olduğunu tespit etmişlerdir.

Clark vd. (2019: 1) derin görüşme ile gerçekleştirdikleri çalışmalarında, iç markalaşmanın yükseköğrenim marka yönetimi stratejisine göre değerli bir rolü olduğunu belirtmişlerdir. İç markalaşma planlama sürecinin ve kampanyasının üniversite başarısını ne derecede etkilediğini göstermektedir. Çalışma yeniden markalaşma sürecinin bütünsel bir görünümünü sunmaktadır. Yeniden markalaşma kampanyasının anlaşılmasını ve bunlarla etkileşime geçilmesini araştırır.

Balaji vd. (2016: 9) öğrenci-üniversite kimliğinin geliştirilmesinde üniversite marka kişiliği, üniversite marka saygınlığı ve üniversite marka bilgisinin rolünü inceleyen bir çalışma yürütmüştür. Araştırmada, marka bilgisi ve marka prestiji üniversite kimliğinin iki temel belirleyicisi olarak belirlenmiştir. Yazarlar, öğrencilerin üniversitenin kimliğini ne kadar çekici algılarlarsa, o derecede kendilerini üniversiteyle özdeşleştireceklerini belirtmişlerdir.

\section{ARAŞTIRMANIN METODOLOJISI}

$\mathrm{Bu}$ araştırmanın temel amacı; Mehmet Akif Ersoy Üniversitesi'nin marka üniversite olma sürecinde hangi adımları uyguladıklarını içerik analizi ile incelemek ve elde edilen 
bulgular sonunda üniversitenin marka yönetim sürecine dair değerlendirmelerde ve önerilerde bulunmaktır. Türkiye' de üniversitelerin markalaşması ve markalaşma süreçleri hususunda sınırlı sayıda çalışma olduğu düşünülmektedir. Bu bağlamda çalışmanın, literatüre katkı sağlaması amaçlanmaktadır.

Çalışmada şu sorulara da cevap aranmaktadır:

- Markalaşma sürecinde paydaşlar bu sürece nasıl katkı sağlamaktadır?

- Üniversitenin hedef kitlesinin istek ve ihtiyaçları nelerdir?

- Üniversitenin güçlü ve zayıf yönleri, firsat ve tehditleri nelerdir?

- Üniversitenin marka imajı nedir?

- Üniversite marka kimliği planlamasını nasıl uygulamaktadır?

- Üniversite markasını nasıl konumlandırmaktadır?

- Üniversite marka iletişim stratejileri nelerdir?

Çalışmada Mehmet Akif Ersoy Üniversitesi'nin marka üniversite olma sürecinde hangi adımları izlediğine dair verilere ikincil kaynaklar ile ulaşılmıştır. Araştırma verileri üniversitenin resmî web sitesinde yer alan bilgiler, 2012 ve 2018 yılları arasında yayımlanan İdare Faaliyet Raporları, Kurum İç Değerlendirme Raporları, 2008-2012 ve 2013-2017 Stratejik Planların analizi ile elde edilmiştir ${ }^{3}$. Bu veriler nitel araştırma yöntemlerinden biri olan içerik analizi ile incelenerek sorulara yanıtlar aranmıştır. İçerik analizi araştırmacı tarafindan tanımlanmış araştırma sorusu açısından önem arz eden anlam içerikleri üzerinde odaklaşan bir arama ve tarama stratejisidir (Bal, 2016: 258). Bir başka ifadeyle, eldeki yazılı bilgilerin temel içeriklerinin ve içerdikleri mesajların özetlenmesi ve belirtilmesi işlemi olarak tanımlanmaktadır (Sert vd., 2012: 2). İçerik analizi belgeleri analiz etme yöntemi olarak da bilinmektedir. Araştırmacıya verilerin anlaşılmasını sağlamak için teorik konuları test etme imkânı sağlar. İçerik analizi sayesinde, kelimeleri daha az sayıda ilişkisel kategoriye ayırmak mümkündür (Elo ve Kyngas, 2007: 108). Yıldırım ve Şimşek’e (2006) göre içerik analizinin temel amacı yazılı, görsel ve işitsel alanlardaki yayınlar irdelenerek elde edilen verileri açıklayabilecek kavramlara ve ilişkilere ulaşmaktır. İçerik analizi verilerin oluşturulması ve kodlanması, temaların bulunması, kod ve temaların organize edilmesi ve bulguların yorumlanması şeklinde dört aşamadan oluşmaktadır (İslamoğlu, 2011). Bu çalışmada da önce veriler düzenlenmiş, temalar tespit edilerek organize edilmiştir. Son aşama olarak ise elde

\footnotetext{
${ }^{3}$ Bildiri olarak sunulan bu çalışma 2017 ve 2018 yılı verileri de çalışmaya dâhil edilerek güncellenmiş ve yayımlanmak üzere hazırlanmıştır.
} 
edilen bulgular Aaker'ın (1996: 79) stratejik marka analizi çalışması uyarlanarak içerik analizine tabi tutulmuştur.

Araştırma verilerinin İdare Faaliyet Raporları, Kurum İç Değerlendirme Raporları, 2008-2012 ve 2013-2017 Stratejik Planları ile analiz edilmesi araştırmanın kısıtlarını oluşturmaktadır.

\section{ARAŞTIRMANIN BULGULARI}

\subsection{Mehmet Akif Ersoy Üniversitesi’nin Markalaşma Sürecinde Paydaşların Katkısı}

Mehmet Akif Ersoy Üniversitesi yönetimi marka üniversite olma yolunda ilk adımı “2008-2012 Stratejik Planında” markalaşmaya dair karar alarak Mehmet Akif Ersoy üniversitesini diğer üniversiteler arasında öne çıkaracak bir kimlik ortaya koymayı hedeflemiştir. Marka üniversite olmak uzun bir süreç gerektirir ve bu bağlamda paydaşların görüş, destek ve önerileri son derece önemlidir. Bunun bilincinde olan üniversite yönetimi, markalaşma yolunda öncelikle tüm iç ve dış paydaşlarını belirleyerek onları da bu sürece dâhil etmiştir. $\mathrm{Bu}$ süreçte üniversite, paydaşlarının görüşlerini alarak bu konuda başarıyla ilerlemektedir (Mehmet Akif Ersoy Üniversitesi, 2016a: 5).

Üniversite dış paydaşların aktif olarak katılımını sağlamak adına çalıştay, toplantı ve çeşitli etkinlikler düzenlemekte, ortaya konan rapor haline getirilerek sektöre sunulmaktadır. $\mathrm{Bu}$ süreçlerin etkin ve verimli bir şekilde yürütülebilmesi için üniversite bünyesinde kurulan birimler ve merkezler, tüm bu adımlarda aktif olarak yer almaktadır. İş birliği faaliyetleri kapsamında akademik personelden oluşan, farklı alanlardan proje danışma ve gerçekleştirme ekiplerinin kurularak şehir ve bölge adına projeler geliştirilmesi teşvik edilmektedir. Şehir ve bölge aktörleri tarafından geliştirilen projelerin hazırlanmasında ve öğrencilerin hazırladıkları projelerde danışmanlık hizmeti verilmektedir (Mehmet Akif Ersoy Üniversitesi, 2016a: 10).

Tablo 2. Paydaşlarla yürütülen eğitim, proje ve danışmalık sayıları

\begin{tabular}{|l|c|c|c|c|c|}
\hline & $\mathbf{2 0 1 4}$ & $\mathbf{2 0 1 5}$ & $\mathbf{2 0 1 6}$ & $\mathbf{2 0 1 7}$ & $\mathbf{2 0 1 8}$ \\
\hline Yürütülmesine destek verilen proje sayısı & 88 & 27 & 27 & 236 & 178 \\
\hline Topluma yönelik verilen eğitim sayısı & 15 & 13 & 32 & 35 & 26 \\
\hline Danışmanlık sayısı & 14 & 19 & 4 & 14 & 21 \\
\hline Dış paydaşlara verilen eğitim sayısı & 15 & 13 & 32 & 25 & 5 \\
\hline
\end{tabular}

Kaynak: 2014- 2018 yılları Burdur Mehmet Akif Ersoy Üniversitesi idare faaliyet raporları 


\subsection{Hedef Kitlenin İstek ve İhtiyaçları}

Üniversite, öğrencilerin istek ve ihtiyaçlarını analiz etmek üzere 6 ayda bir öğrenci memnuniyet anketi uygulamaktadır. Ayrıca iç paydaşlarına da önem vererek akademik personel memnuniyet anketi uygulamaktadır (Mehmet Akif Ersoy Üniversitesi, 2016c). Ergün (2014: 228) üniversite- kent ilişkisi üzerine yaptığı çalışmasında Mehmet Akif Ersoy Üniversitesi öğrencileri üniversitenin en olumlu yanlarının 'yeni gelişmekte olan bir üniversite olması', ‘öğretim elemanı- öğrenci ilişkisinin iyi olması' ve 'memleketlerine yakın olması' olarak belirtmişlerdir. En olumsuz yanlarını ise 'kampüsün şehir merkezinin dışında olması', 'ulaşım sorununun olması ve kampüs otobüslerinin geç gelmesi' ve 'üniversitede gerçekleşen aktivitelerin az olması ve öğrencilerin olan aktivitelerden haberdar edilmemesi' olarak belirtmişlerdir. Olumsuz yanların giderilmeye çalışılması ve belirli periyotlarla ihtiyaç analizi yapılarak daha etkili faaliyetler planlanabilir. Ayrıca üniversite 2018 yılında bir önceki yıla göre öğrenim deneyimi tatminkârlığı puanını en fazla yükselten en iyi 3 üniversite arasındadır (Mehmet Akif Ersoy Üniversitesi, 2018b: 41).

Tablo 3. Burdur Mehmet Akif Ersoy Üniversitesi memnuniyet düzeyleri

\begin{tabular}{|l|c|c|c|c|c|}
\hline & $\mathbf{2 0 1 4}$ & $\mathbf{2 0 1 5}$ & $\mathbf{2 0 1 6}$ & $\mathbf{2 0 1 7}$ & $\mathbf{2 0 1 8}$ \\
\hline Öğrenci memnuniyet düzeyi (\%) & - & 75 & 64 & 68 & 70 \\
\hline Öğretim elemanı memnuniyet düzeyi (\%) & - & 69 & 84 & 69 & 72 \\
\hline Sosyal ve kültürel hizmetlerdeki öğrenci memnuniyet düzeyi (\%) & - & 65 & 61 & 62 & 66 \\
\hline Sosyal ve kültürel hizmetlerdeki personel memnuniyet düzeyi (\%) & - & 63 & 63.5 & 67 & 69 \\
\hline
\end{tabular}

Kaynak: 2014- 2018 y1lları arası Burdur Mehmet Akif Ersoy Üniversitesi idare faaliyet raporları

\section{3. Üniversitenin Güçlü ve Zayıf Yönleri}

Stratejik planlama süreci kapsamında çalıştaylar düzenlenerek üniversitenin güçlü ve zayıf yönleri, fırsat ve tehditlerini (GZTF) belirlemeye yönelik analizler yapılmıştır. Üniversitenin 2008-2012 stratejik planında tehdit olarak görülen 'Şehrin sosyal olanaklarının yetersiz olması nedeniyle çekim oluşturamaması' ve 'Şehrin sanayi, turizm ve hizmet sektörü açısından yeterince gelişememiş olması' halen tehdit olarak devam etmektedir. Ayrıca 'Üniversite sayısının ve rekabetin artması' 2017- 2021 Stratejik planında tehditler kısmına eklenmiştir.

Zayıf görülen bazı noktalarda düzeltilme yoluna gidilmiştir. Üniversiteye olumsuz etkisi olduğu düşünülen merkezdeki akademik birimlerin dağınık yerleşkelerde olmaları; öğrencilerin barınma ve ulaşım sorununun giderilmesiyle beraber çözüme kavuşturulmuştur. Günden güne 
fiziki ve teknolojik alt yapının artmasıyla üniversitenin yerleşke alanında olmamasının getirdiği olumsuzluk giderilmiştir. Üniversite; şehirde yaşamın ucuz, rahat ve kolay olması, bölgenin sosyal olarak huzurlu ve güvenli olması, şehrin eğitim düzeyinin çok yüksek olması ve adını eğitimle duyurması, çevrenin araştırma ve uygulamalara açık olması gibi firsatları kullanarak zayıf görülen özelliklerini düzeltmiştir.

\subsection{Mehmet Akif Ersoy Üniversitesi’nin Marka İmajı}

Mehmet Akif Ersoy Üniversitesi'nin imajını tespit edebilmesi için kapsamlı bir çalışmaya ihtiyaç vardır. Üniversitenin hedef kitle tarafından nasıl algılandığının bilinmesi markalaşma sürecinin önemli adımlarından biridir. Üniversiteye hazırlanan öğrencilere yönelik tanıtım faaliyetlerinin artırılması ve bu öğrencilerin üniversitenin imajı hakkındaki görüşlerini elde etmek üzere online anketler düzenlenmelidir. Aday öğrencilerin kampüs ortamına çekilerek burada bir süre olumlu deneyim yaşamaları onların bakış açılarını değiştirecek ve onların bu ailenin bir üyesi olma isteklerini artıracaktır.

Burdur' un imajının belirlenmesine yönelik çalışmalar mevcuttur. Yapılan bu çalışmalar Mehmet Akif Ersoy Üniversitesi' nin imajına olumlu olarak etki etse de direkt üniversitenin imajına yönelik yapılan bir çalışmaya rastlanmamıştır. Burdur’ un sahip olacağı kent imajı üniversitenin imajını da olumlu olarak etkileyecektir. Örneğin, Burdur' un imajı ile ilgili yapılan çalışmada (Demirel, 2014: 239) üniversite öğrencilerinin hem Burdur halkına hem de Burdur kentine yönelik algılarının orta düzeyde olduğunu belirlenmiştir. Öğrencilerin kentin soyut imajına yönelik algıları sırasıyla kentin sakin, güvenli ve temiz oluşudur. Bir başka araştırmada Köksal ve Sarı (2014: 287) halkın genel imaja kısmen olumlu baktığını, üniversite öğrencilerinin ise, olumsuz görüş belirttiklerini tespit etmişlerdir. Araştırmaya katılan öğrenciler kentin yeterince gelişmemiş olduğunu, kültürel ve sanatsal etkinliklerin az olduğunu, ticari faaliyetlerin ve alışveriş noktalarının yeterli sayıda olmadığını, aranan her şeyin kentte kolayca bulunamadığını ve kentin yeterince tanıtılmadığını düşünmektedir.

\subsection{Mehmet Akif Ersoy Üniversitesi’nin Marka Kimliği}

Üniversite Markasının Kalitesi: Mehmet Akif Ersoy Üniversitesi toplam kalite yönetim anlayışı çerçevesinde tüm eğitim, araştırma ve yönetim süreçlerini iç ve dış paydaşlarının katkılarıyla iyileştirerek sürekli gelişimi sağlamaktadır (Mehmet Akif Ersoy Üniversitesi, 2017b). Eğitim ve öğretim, araştırma ve geliştirme, yönetim sistemi kalite alt komisyonları 
bulunmasına rağmen üniversite markasının kalitesine yönelik herhangi bir çalışmaya rastlanmamıştır. Bu alanda yapılacak çalışmalar, markalaşma sürecine katkı sağlayacaktır.

Hedef Kitle: Üniversitenin en önemli hedef kitlesini öğrenciler oluşturmaktadır. Aldığ1 eğitimden memnun olarak ayrılan öğrenciler üniversitenin gönüllü tanıtım elçisi olacaklardır. Üniversitenin diğer hedef kitlesi akademik personel, idari personel, potansiyel öğrenciler, ortaöğretim kurumları, fikir liderleri, yerel yönetimler ve sivil toplum kuruluşları, genel kamuoyu ve medyadır (Mehmet Akif Ersoy Üniversitesi, 2008: 39).

Üniversite; eğitim öğretim alanında hizmet etmenin yanı sıra bölgenin kalkınmasına da katkı sağlama çabasındadır. Bünyesinde bulunan Burdur Gelişim Merkezi ile üniversite- sanayi iş birliği ile çalışmalar yürütülmektedir. Üniversitelere ilişkin olarak çeşitli kuruluşlarca yapılan sıralamalar, rekabette farklılaşma ihtiyacı, hedef öğrenci kitlesi ile doğru iletişimi kurabilmek adına üniversitelerin markalaşma çabalarının önem kazandığının farkında olan üniversite, marka değeri oluşturma çabalarını bilinirlik odaklı gerçekleştirmeyi hedeflemektedir (Mehmet Akif Ersoy Üniversitesi, 2017d).

Kaynak Ülke veya Bölge: Üniversite kendini Batı Akdeniz Bölümünde küçük bir şehrin can damarında yer alan Mehmet Akif Ersoy Üniversitesi ailesi olarak konumlandırmaktadır (Mehmet Akif Ersoy Üniversitesi, 2017a). Burdur kentinin sosyal imkânlarına bakıldığında üniversitenin kentin gelişimine ve ekonomisine katkı sağladığı görülmektedir.

Marka-Hedef Kitle İlişkisi: Öğrencilerin sosyal yaşamını ve memnuniyetini artırmak için 2017 y1lında Öğrenci Destek Merkezi (ÖDEMER) devreye girmiştir. Mehmet Akif Ersoy Üniversitesi’nin öğrenci odaklı eğitim anlayışına katkıda bulunmayı, öğrencilerin karşılaşabilecekleri sorunlara koruyucu ve önleyici çalışmalar yaparak yardımcı olmayı, problemler karşısında öğrencilerin var olan potansiyellerini kullanmalarını, sağlıklı ve doğru kararlar almalarını sağlamayı amaçlamaktadır (Mehmet Akif Ersoy Üniversitesi, 2017e). Üniversite tarafından Öğrenci Destek Merkezine başvuran öğrencilerin hangi amaçla başvurduklarını ve bu sorunlara karşı hangi çözüm önerilerinin sunulduğunun paylaşılması hem daha şeffaf bir yönetim yapısı olduğunu ortaya koyacak hem de öğrencilerin memnuniyet seviyesini artıracaktır.

Üniversitede, öğrencilerle olan iletişimi sürekli hale getirmek amacıyla oluşturulan mezun takip sistemi 2017 yılında aktifleştirilmiştir. Bu sistemin amacı; üniversitenin, mezun öğrencilerle olan iletişimini sürdürmenin yanı sıra, mezunların hangi kurum ve kuruluşlarda 
istihdam edildikleri, hangi statüde ve hangi birimlerde çalıştıkları, tercih edilme nedenleri, yükselme olanakları ile ilgili bilgileri elde etmektir. Sistemden elde edilecek bilgiler, üniversitenin eğitim kalitesinin artırılmasına, mezunların iş olanaklarının artmasına, ilgili kurum ve kuruluşların kaliteli, mesleki bilgi ve beceriye sahip elemanları istihdam etmelerine katkı sağlayacaktır (Mehmet Akif Ersoy Üniversitesi, 2017d). Bilgi İşlem Daire Başkanlığı ile Mezunlarla İlişkiler ve Kariyer Planlama Koordinatörlüğü tarafından geliştirilen web tabanlı uygulama 'Kariyer Okulu' hizmete girmiştir. Kişilik, Mesleki İlgi, Duygusal Zekâ ve İş Değerleri envanterleri ile öğrenciler kendilerini keşfetmekte ve kariyer danışmanları tarafından kendilerine uygun mesleklere yöneltilmektedirler (Mehmet Akif Ersoy Üniversitesi, 2018). Ayrıca hedef kitleyi oluşturan öğrencilerin karar alma süreçlerine daha etkin katılım sağlayacakları ortamların oluşturulması, öğrencilerin üniversite ile daha yakın bağ kurmalarını sağlayacaktır.

Üniversite, öğrencilerine aile gibi yaklaşarak onlara mutlu bir yaşam alanı sunmayı amaçlamaktadır. Her yıl Mayıs ayı içerisinde Bahar ve Bilim Şenlikleri düzenlenerek öğrencilerin sosyal faaliyetlerde bulunmaları ve birbirleriyle kaynaşmaları sağlanmaktadır. 2007 yılından itibaren 11 Bahar şenliği düzenlenmiştir. Üniversite maddi durumu yetersiz öğrencilere sağladığı burslarla başarılı öğrencileri bünyesine kazandırmaktadır. 2018- 2019 eğitim öğretim y1lında 2 engelli, 8 milli sporcu olmak üzere toplam 236 öğrenci öğle yemeği yardımından faydalanmıştır. Ayrıca acil durumlarda öğrencilere hizmet verebilmek adına Sağlık Bakanlığı iş birliği ile 112 Acil İstasyon hizmeti yürürlüğe girmiştir (Mehmet Akif Ersoy Üniversitesi, 2018).

Bünyesinde bulunan Özel Gereksinimli Öğrenci Birimi ile üniversitede öğrenim gören engelli öğrencilerin hayatını kolaylaştırabilmek için gerekli tedbirleri almakta, 'Engelsiz Üniversite' kimliğini taşımak istemektedir. Üniversite öğrencilerinin ders dışı zamanını değerlendirmek, öğrencilerin kültürel gelişimlerine yardımcı olmak amacıyla kültürel etkinlikler düzenlenmekte, üniversite öğrencilerinin istekleri doğrultusunda sanat ve spor dünyasında tanınmış birçok sanatçı ve bilim adamı konuk edilmektedir (Mehmet Akif Ersoy Üniversitesi, 2017a).

Üniversitede sosyal alanların artırılmasına ve bilimsel faaliyetlerine yönelik fiziki alt yapı eksikliklerinin giderilmesi için çalışmalar yapılmaktadır. Öğrencilere, personele, şehre ve bölgeye sosyal ve kültürel imkânlar (projesi devam etmekte olan motor sporları parkuru, bisiklet yolu projesi, olimpik yüzme havuzu, voleybol sahaları, vb.) sunulmaktadır (Mehmet 
Akif Ersoy Üniversitesi, 2016a: 33). Öğrencilere sosyal ve kültürel gelişim imkânının sunulması ile öğrenciler hem üniversitede daha fazla zaman geçirebilecek hem de akademik olarak çalışmaya motive olabileceklerdir. Öğrencilerin bu faaliyetlerden tatmin olarak ayrılmaları ise onların üniversite markası ile duygusal bağ oluşturmasını sağlayacak ve mezun olduktan sonra dahi üniversite hakkında olumlu düşünecek ve mutlu olacaktır.

Tablo 4. Mehmet Akif Ersoy Üniversitesi bünyesinde düzenlenen etkinlikler

\begin{tabular}{|l|c|c|c|c|c|}
\hline & $\mathbf{2 0 1 4}$ & $\mathbf{2 0 1 5}$ & $\mathbf{2 0 1 6}$ & $\mathbf{2 0 1 7}$ & $\mathbf{2 0 1 8}$ \\
\hline $\begin{array}{l}\text { Üniversite bünyesinde düzenlenen kongre, panel, sempozyum, } \\
\text { konferans vb bilimsel etkinlik sayısı }\end{array}$ & 119 & 175 & 137 & 140 & 217 \\
\hline $\begin{array}{l}\text { Üniversite bünyesinde düzenlenen sosyal, kültürel ve spor etkinliği } \\
\text { sayısı (konser, tiyatro, sergi, şenlik, spor etkinliği. vb.) }\end{array}$ & 141 & 138 & 149 & 141 & 166 \\
\hline
\end{tabular}

Kaynak: 2014-2018 y1lları arası Burdur Mehmet Akif Ersoy Üniversitesi idare faaliyet raporlar1

Üniversite Yayınlarl: Üniversite yayınları; online bülten, üniversite tanıtım fotoğrafları, online gazete, online dergi, broşürler, üniversite raporları, mali tablolar, e- kitap ve üniversite tanıtım filmlerinden oluşmaktadır (Çiçek vd., 2010: 199).

Tablo 5. Üniversitenin yayınları ${ }^{4}$

\begin{tabular}{|l|c|c|c|c|c|}
\hline & $\mathbf{2 0 1 4}$ & $\mathbf{2 0 1 5}$ & $\mathbf{2 0 1 6}$ & $\mathbf{2 0 1 7}$ & $\mathbf{2 0 1 8}$ \\
\hline Basılı kitap ve dergi sayıs1 & 42.931 & 47.508 & 50.606 & 56628 & 63522 \\
\hline Elektronik kitap ve dergi sayıs1 & 109.281 & 172.507 & 207.816 & 241323 & 211016 \\
\hline Veri tabanı sayıs1 & 25 & 24 & 24 & 33 & 21 \\
\hline Ulusal makale sayıs1 & - & - & - & 279 & 299 \\
\hline Uluslararası makale sayıs1 & - & - & - & 478 & 396 \\
\hline Ulusal bildiri sayıs1 & - & - & - & 163 & 125 \\
\hline Uluslararası bildiri sayı1s1 & - & - & - & 1432 & 1052 \\
\hline Üniversitede yayınlanan akademik dergi sayıs1 & - & - & - & 5 & 6 \\
\hline Ulusal yayın sayıs1 & 380 & 453 & 453 & - & - \\
\hline Uluslararası yayın sayıs1 & 83 & 135 & 135 & - & - \\
\hline
\end{tabular}

Kaynak: 2014-2018 yılları arası Burdur Mehmet Akif Ersoy Üniversitesi idare faaliyet raporları ve 2017-2018 yılı kurum iç değerlendirme raporu

Yerel veya Global Olma: Üniversite yerel faaliyetlerinin yanı s1ra uluslararası mecralarda da kendine yer edinmek istemektedir. Gerçekleştirilen Uluslararası Mehmet Akif Ersoy Sempozyumu ve Bilim Sanat Ödülleri Töreni ile üniversite hem marka olma yolunda önemli bir adım atmıştır hem de uluslararası düzeyde bilinirliğini artırmıştır.

\footnotetext{
4 2014- 2016 yılları verileri ulusal ve uluslararası yayın sayısı olarak belirtilmiş, 2017 ve 2018 yılı İdare Faaliyet Raporlarında detaylı veriler sunulmuştur.
} 
Yurtdışı Benchmarking, yurtiçi ve yurtdışı öğrenci ve öğretim elemanı değişimi protokolleri yapılmıştır. Yapılan ikili anlaşmalar Farabi, Erasmus ve Mevlâna öğrenci değişim programlarıdır (Mehmet Akif Ersoy Üniversitesi, 2017a). Böylece üniversiteye yurtdışından ya da diğer üniversitelerden gelecek olan öğrencilerin üniversiteden memnun olarak ayrılmaları, üniversite kimliğini ve imajını doğru bir şekilde algılamaları, potansiyel öğrencilere ya da paydaşlara iyi bir şekilde aktarımını sağlayacaktır.

Üniversitenin bilinirliğini arttırmak için belirlenen performans göstergeleri şunlardır (Mehmet Akif Ersoy Üniversitesi, 2016d: 59): Ranking Web of Universities siralaması, URAP sıralaması, Girişimci ve yenilikçi üniversite indeksi, YGS'de MAKÜ’yü ilk 3 tercihinde bulunduran öğrenci oranı, Ulusal medyada üniversitenin haber sayısı.

Ranking Web of Universities sıralamasında 2018 yılında 6059 olarak yer almış ve her y1l bir üst sıralarda yer almak hedeflenmiştir. URAP sıralamasında 2018 yılında 88. olarak yer almış, girişimci ve yenilikçi üniversite indeksinde yer almadığı belirtilmiştir (Mehmet Akif Ersoy Üniversitesi, 2018a). YGS' de MAKÜ' yü ilk 3 tercihinde bulunduran öğrenci oranı \%22, ulusal medyada üniversitenin haber sayısı 2357'dir (Mehmet Akif Ersoy Üniversitesi, 2016a: 75).

Tablo 6. Değişim programları ile gelen ve giden öğrenci ve öğretim elemanı sayıları

\begin{tabular}{|c|c|c|c|c|c|}
\hline & 2014 & 2015 & 2016 & 2017 & 2018 \\
\hline $\begin{array}{l}\text { Ulusal öğrenci değişim programına katılan öğrenci sayısı } \\
\text { (Giden öğrenci) }\end{array}$ & 72 & 102 & 26 & 35 & 48 \\
\hline $\begin{array}{l}\text { Uluslararası öğrenci değişim programına katılan öğrenci sayısı } \\
\text { (Giden öğrenci) }\end{array}$ & 110 & 72 & 109 & 172 & 130 \\
\hline $\begin{array}{l}\text { Uluslararası öğrenci değişim programına katılan öğrenci sayısı } \\
\text { (Gelen öğrenci) }\end{array}$ & 22 & 37 & 11 & 4 & 2 \\
\hline $\begin{array}{l}\text { Uluslararası öğretim elemanı değişim programına katılan } \\
\text { öğretim elemanı sayısı (Giden öğr. elm.) }\end{array}$ & 92 & 30 & 21 & 48 & 44 \\
\hline $\begin{array}{l}\text { Uluslararası öğretim elemanı değişim programına katılan } \\
\text { öğretim elemanı sayısı (Gelen öğr. elm). }\end{array}$ & 15 & 15 & 4 & 5 & 12 \\
\hline
\end{tabular}

Kaynak: 2014-2018 y1lları arası Burdur Mehmet Akif Ersoy Üniversitesi idare faaliyet raporları

Marka Kişiliği: Aysen vd. (2012: 182) Ankara’da eğitim gören üniversite öğrencilerinin marka kişiliği algılarını ölçmek ve üniversite marka kişiliklerinin öğrenciler tarafından algılanışının farklı olup olmadığını tespit etmek amacıyla yapılan analizlerde vakıf ve devlet üniversitesi öğrencilerinin, üniversitelerine yönelik algıladıkları marka kişiliklerinin farklı olmadığını tespit etmişlerdir. Tayfur vd. (2017: 241) ise Sakarya Üniversitesi marka kişiliğinin hangi faktörler altında toparlanabildiğini belirlemek ve böylece Sakarya Üniversitesinde 
okuyan öğrenciler tarafından üniversitenin marka kişiliğini etkileyen faktörleri tespit etmek üzere çalışma yapmışlardır. Literatürde üniversitelerin marka kişiliğine dair çalışmalar olmasına rağmen Mehmet Akif Ersoy Üniversitesinin marka kişiliğine dair herhangi bir çalışmaya rastlanmamıştır. Üniversitenin marka kişiliğini belirlemeye yönelik yapılacak çalışmalar ile üniversitenin markalaşma sürecine olumlu katkı sağlanacaktır.

Mehmet Akif Ersoy Üniversitesi' nin İsmi: Mehmet Akif Ersoy Üniversitesi adını ünlü şairimiz Mehmet Akif Ersoy' dan almaktadır. 1. TBMM'de Burdur milletvekili olarak görev alan Mehmet Akif Ersoy, Burdur ilinin önem verdiği, benimsediği bir şahsiyettir. Bu isim kurtuluşun ilimde ve irfanda olduğuna iman derecesinde inanan bir ufuk adamının ismidir. Şaire verilen bu önem ve İstiklal Marşı’ mızın yazarı olması vesilesiyle üniversiteye onun adı verilmiştir (Mehmet Akif Ersoy Üniversitesi, 2017a). Geçmişte bir milletin direnişine 1şık tutan, onu cesaretlendiren ve destanlar yazdıran bir ismin üniversite ismi olarak seçilmesi, üniversitenin nasıl yüksek hedef belirlediğini ve başarılı olma iddiasını yansıtmaktadır.

Son dönemde kurulan üniversiteler yerel ve ulusal kalkınmaya destek olma gayesiyle hareket etmekte ve genellikle bulundukları kentin adıyla anılmaktadırlar. Örneğin; Bartın Üniversitesi, Amasya Üniversitesi, Gaziantep Üniversitesi. Mehmet Akif Ersoy Üniversitesi de bölgenin kalkınmasında aktif rol almayı hedeflemekte ve bilinirlik odaklı çalışmalar yapmaktadır. Bu amaçla ismini Burdur Mehmet Akif Ersoy Üniversitesi olarak değiştirmiştir.

Logo ve Amblem: Mehmet Akif Ersoy Üniversitesi, yeni nesillerin öncüsü olacak bilim yuvalarından birini oluşturmayı hedeflediğinden doğayı, bilimi, teknolojiyi ve Burdur ilini temsil etmek maksadıyla amblemini tasarlamıştır. Bu amblemde her yıl Burdur iline göç eden flamingolardan esinlenilmiştir. Flamingoların kullanılması çevre ve doğa bilinci mesajı da vermektedir. Amblemde kullanılan kırmızı renk enerji verir, mutluluğu temsil eder, insanları canlandırır ve heyecan vericidir. Burdur Gölü’nü temsilen de mavi renk kullanılmıştır. Mavi renk ise yaratıcılığ 1 , ciddiyeti, güvenirliliği ve idealizmi temsil eder. Amblemde vurgulanmak istenen; Mehmet Akif Ersoy Üniversite'nin dinamik, yaratıc1, bilim ve teknolojiyi bir arada bulunduran yapısıdır (Mehmet Akif Ersoy Üniversitesi, 2017c). Mutluluk ve enerjinin odağında hedef kitlenin memnuniyetinin önemsenmesi ve her öğrencinin üniversiteden mutlu olarak, akademik ve sosyal gelişiminden tatminkâr biçimde üniversiteden ayrılmaları marka imajına ve kimliğine olumlu yansıyacaktır. 
Slogan: Sloganlar tekrarlanarak insanların zihninde yer eden sözlerdir. Mehmet Akif Ersoy Üniversitesi’ nin sloganı ‘İstiklalden İstikbale’ dir. Üniversite, geçmişten aldığı ilhamla geleceğe 1şık tutmaya odaklanmakta ve bu hedefini de sloganlarına yansıtmaktadır.

\subsection{Mehmet Akif Ersoy Üniversitesi’nin Konumlandırması}

Mehmet Akif Ersoy Üniversitesi markalaşma yolunda Marka Şehir- Marka Üniversite konseptinde ilerlemektedir. Marka bir şehirde marka üniversite olarak konumlanmanın sağlayacağı avantajların farkındadır.

Burdur eğitim ile kendini ön plana çıkaran bir ildir. 2018 ÖSYM verilerine göre YKS' de Türkiye'de 11. sırada, LGS' de Türkiye 23. olmuştur. TÜİK 2015 yılı verilerine göre okuryazar oranı \%96,7 dir. Üniversite; kentin ilim yuvası kimliğini taşıma gayretindedir. Bunun için alanında en iyi fakülteleri hayata geçirmek ve öğrencilerin hizmetine sunmak gerekliliğini hissetmekte ve Burdur halkından da bu konuda kendilerine destek beklemektedir (Mehmet Akif Ersoy Üniversitesi, 2017d).

Üniversite “'Hayvancılık ve Hayvancılığa Dayalı Sanayiciliğin Geliştirilmesi” ' alanında Kalkınma Bakanlığı tarafından desteklenecek 5 pilot üniversiteden biri seçilmiştir. Mehmet Akif Ersoy Üniversitesi yöre ile ilintili olarak hayvancılık, hayvancılığa dayalı sanayi ve özellikle gıda sanayi konusunda konumlandırma çalışmaları yapmaktadır. Tarımsal sanayiye, özellikle hayvancılık ve hayvan yetiştiriciliğine, hayvancılığa dayalı faaliyetler ve sanayiye özel olarak odaklanmayı amaçlamaktadır (Mehmet Akif Ersoy Üniversitesi, 2017d). Burdur Mehmet Akif Ersoy Üniversitesi Tarım ve Hayvancılık Projesi Koordinatörlüğü oluşturularak çalışmalar yürütülmektedir. MAKÜ Çiftçi Okulu ile paydaşlara eğitimler düzenlenerek verimli üretim gerçekleştirmelerine katkı sağlanmaktadır.

Tablo 7. 2018 yılı yürürlükteki ve sonuçlanan proje sayıları

\begin{tabular}{|l|c|c|}
\hline Türü & $\begin{array}{c}\text { Yürürlükteki } \\
\text { Proje Sayısı }\end{array}$ & $\begin{array}{c}\text { Sonuçlanan } \\
\text { Proje Sayısı }\end{array}$ \\
\hline Yüksek Lisans & 116 & 51 \\
\hline Doktora & 13 & 3 \\
\hline AYDEP (Alt Yapı Destek Projeleri) & 8 & 20 \\
\hline Güdümlü & 3 & 3 \\
\hline Normal Araştırma & 17 & 1 \\
\hline HAYDEP(Hayvancılık Destek Projeleri) & 1 & - \\
\hline
\end{tabular}

Kaynak: 2018 Burdur Mehmet Akif Ersoy Üniversitesi kurum iç değerlendirme raporu 
Gürbüz, C., Çetinkaya Bozkurt, Ö. \& Dal, N. E.

\subsection{Mehmet Akif Ersoy Üniversitesi’nin İletişim Stratejileri}

Mehmet Akif Ersoy Üniversitesi tüm etkinlik, haber ve organizasyonlarını web sitesi aracılığıyla duyurmaktadır. 2009 yılı itibariyle 6107 duyuru web sitesinde yayınlanmıştır. Her bir fakültenin web sitesi bulunmaktadır. Yörede bulunan dergilere üst yönetim tarafından röportajlar verilerek üniversitenin kendini anlatmasına firsat tanınmaktadır. Ayrıca genel ve öğretim elemanı duyurularına Mehmet Akif Ersoy Üniversitesi Öğrenci Bilgi Sistemi’nden erişim sağlanmaktadır.

Üniversite bünyesinde yayımlanan ulusal ve uluslararası hakemli dergilere, üniversiteye ait tüm plan ve raporlara web sitesinden kolay erişim sağlanmaktadır. Web sitesinde yer alan tanıtım kataloğu ile hem görsel hem de yazılı olarak üniversiteyi tanıtıcı bilgilere yer verilmektedir. Burada öğrencilerin neden Mehmet Akif Ersoy Üniversitesini tercih etmeleri gerektiği belirtilmekte, üniversitenin hedef kitleye sunduğu tüm imkânlar anlatılarak hem üniversite markasının hedef kitleye doğru biçimde aktarımı yapılmakta hem de nitelikli öğrenciler üniversite bünyesine çekmeye çalışılmaktadır (Mehmet Akif Ersoy Üniversitesi, 2017a).

Üniversitenin tanıtım fïlmi güncel olarak, Türkçe ve İngilizce alt yazılı olmak üzere sitede yer almaktadır. Bu sayede üniversite ulusal ve uluslararası hedef kitlesine görsel ve işitsel olarak hitap etme imkânı bulmaktadır.

Üniversite tercih dönemlerinde de üniversite adaylarına tercih yapmalarında destek sağlanması ve onlara üniversite hakkında açıklayıcı ve tanıtıcı bilgiler verilmesi de üniversiteye artı değer katacaktır.

Üniversite-Medya İlişkileri: Üniversite ile ilgili yayımlanan haberler 'Basında Üniversitemiz' başlığı altında yayımlanmakta, haberlerin yayımlandığı tarih ve gazete adına yer verilerek hedef kitlenin dikkatine sunulmakta ve arşivlenmektedir. 2016- 2018 y1lları arasında üniversite ile ilgili 2004 yayın bulunmaktadır. Kullanıcılar ilgili haberlere kolay erişim sağlamakta aynı zamanda 'arama' kısmından da istedikleri haberlere kolayca ulaşmaktadırlar.

Web sitesinde yer alan akademik takvim ile eğitim- öğretim ile ilgili planlamalar yapılmakta, etkinlik takvimi ile yapılacak etkinliklere ait liste yer almaktadır.

Üniversite bünyesinde yapılan araştırma faaliyetlerinin sonuçları yayın, konferans, sempozyum, paneller, TV, web sayfası, yerel basın vb. etkinliklerle ile duyurulmakta, bu 
konuda toplumu bilgilendirme için gerekli enstrümanlar kullanılmaktadır. Her bir birimin yapmış olduğu bilimsel etkinlikler faaliyet raporlarında kayıt altına alınmakta ve düzenlenen her tür etkinlik MAKÜ Basın Yayın tarafından da izlenmektedir. Bu sayede yapılacak etkili tanıtım faaliyetleri ile üniversite bilinirliğini artıracaktır.

Üniversite İletişim Bilgi Çabalarl: Üniversitenin web sitesinde öğrenci memnuniyetini ölçmek amacıyla online anket formu yer almaktadır. Ayrıca bilgi edinme başvuru formu ve Bimer bağlantısı bulunmaktadır. ÖDEMER sistemi üzerinden öğrenciler için talep/ şikâyet/ öneri rektöre gönderilmek üzere form bulunmaktadır.

Facebook ve Twitter üzerinden Mehmet Akif Ersoy Üniversitesi ile ilgili bilgi ve uygulamalara erişilebilmektedir. Bu mecralar üzerinden de yorum, şikâyet ve önerilerde bulunulabilmektedir. Sosyal medya platformları sayesinde hedef kitleye ulaşmak ve onlarla etkili iletişimde bulunmak, duyuru ve etkinlikleri buradan yayımlayarak daha fazla kişiye ulaşmak mümkündür.

Üniversite mobil cihazlar için, hızlı ve etkin bir biçimde üniversite ile ilgili bilgilere ulaşmak amacıyla özel olarak ios ve androidler için yazılım geliştirmiştir. Mobil uygulama ile duyurular, etkinlikler, kitap tarama vb. bilgilere erişim sağlanmaktadır.

MAKÜSOSYAL uygulaması ile öğrenciler; üniversitedeki gelişmelerden haberdar olabilir, not durumlarını görüntüleyebilir, kütüphanede kitap taraması yapabilir ve üniversitenin tüm birimleri ile Burdur şehrinin önemli yerlerini harita üzerinde görüp yol tarifi alabilirler. Ayrıca katıldıkları bilimsel, kültürel, sanatsal ya da sportif tüm etkinliklerden puan toplayabilir ve mezun olduklarında alacakları SOSYAL DIPLOMA ile katıldıkları etkinlikleri belgeleyebilirler.

Reklam Faaliyetleri: Reklam faaliyetleri reklam filmleri, televizyon reklamı, radyo reklamı ve basılı reklamı içermektedir. Pazar araştırması, reklam, sponsorluk, medya iletişim vb. konularda çalışmaları sürdürmek amacıyla Kurumsal İletişim ve Uygulama Merkezi açılmıştır. $\mathrm{Bu}$ sayede markalaşma çalışmaları profesyonel ve daha etkin bir biçimde sürdürülecektir.

Kentine yönelen üniversite vizyonu doğrultusunda Burdur PTT Başmüdürlügü ile yapılan iş birliği doğrultusunda Kurumsal İletişim Uygulama ve Araştırma Merkezi tarafından Burdur ilini tanıtıcı yeni yıl kartpostalları hazırlanmıştır. Kartpostallar üniversiteye yeni kayıt yaptıran öğrencilerin ve ailelerinin yeni yıllarını kutlamak üzere gönderilmiştir. Bu sayede 
Burdur'un tanıtımına katkı sağlanması planlanmıştır. Yine PTT iş birliği ile Mehmet Akif Ersoy'un bir portresi kişisel pul olarak bastırılarak kartpostal gönderimlerinin üzerine bu pul yapıştırılmıştır. Bu sayede Mehmet Akif isminin yüceltilmesine ve yaşatılmasına da katkı sağlanması hedeflenmiştir (Mehmet Akif Ersoy Üniversitesi, 2017a).

Web sitesinde yer alan Makü TV ile üniversiteyi ilgilendiren tüm etkinlikler, tanıtım, kültür- sanat, bilim- teknoloji ile ilgili videolar 2015 yılı itibariyle yayımlanmaktadır. Ayrıca Veterinerlik Fakültesi tarafından hazırlanan ve yerel tv' de yayınlanan 'ÇİFTLİK' programına ait bölümler de burada yayınlanmaktadır.

Tablo 8. MAKÜ TV' de yayınlanan video sayıları

\begin{tabular}{|l|c|}
\hline Kategoriler & Yayınlanan Video Sayısı \\
\hline Basında Biz & 258 \\
\hline Bilim ve Teknoloji & 6 \\
\hline Etkinlikler & 34 \\
\hline Fakültelerden & 36 \\
\hline Kültür- Sanat & 4 \\
\hline Tanıtım & 8 \\
\hline Topluluklar & 29 \\
\hline Tv Programları & 67 \\
\hline Üniversitemizden & 146 \\
\hline
\end{tabular}

Kaynak: Burdur Mehmet Akif Ersoy Üniversitesi resmî web sitesi

\section{SONUÇ VE ÖNERILER}

Üniversiteler günümüzde ihtiyaç duyulan ileri düzeydeki yüksek nitelikli insan gücünü eğiten, gelecekteki hedefleri doğrultusunda bilimsel araştırmalar yapan kurumlardır. Nitelikli öğrenci ve öğretim elemanlarını bünyesinde barındırarak eğitim kalitesini üst seviyelere taşımak, ulusal ve uluslararası bilinirliğini artırmak ve rekabet ortamında en üst sıralarda yerini almak isteyen üniversiteler için markalaşma zorunlu olmaktadır. Çalışmanın amacı Mehmet Akif Ersoy Üniversitesi' nin marka üniversite olma sürecinde hangi adımları uyguladığını içerik analizi ile incelemek ve üniversitenin marka yönetim sürecine dair değerlendirmelerde ve önerilerde bulunmaktır. Bu kapsamda marka ve marka stratejileri ile ilgili kavramlar incelenmiş, üniversitelerde marka yönetimi için uygulanan adımlar verilmiş ve son olarak Mehmet Akif Ersoy Üniversitesi’nin marka yönetim süreci değerlendirilmiştir.

Türkiye'deki marka üniversitelerden biri olan Boğaziçi Üniversitesi ulusal ve uluslararası mecralarda bilinen, eğitim ve araştırma performansı ile öne çıkan bir üniversitedir. Bu sayede Türkiye’ nin en iyi öğrencileri ve en seçkin öğretim üyelerini bünyesinde bir araya getirmektedir. 'Bizler Dünyayı Değiştirebiliriz’ sloganı ile fark yaratan Orta Doğu ve Teknik 
Üniversitesi de bölgesinde saygı gören uluslararası bir araştırma üniversitesidir. Üniversite sınavına giren öğrencilerin sadece en üstteki yüzde üçlük dilime girenleri kabul etmektedir. Dünyanın kaderini değiştiren araştırmalar yapan bilim insanlarını yetiştiren Harvard Üniversitesi, yüksek eğitim standartlarına sahip olması ile ön plana çıkmaktadır. Üniversite, dünyanın en büyük akademik kütüphanesine ve tüm kütüphaneler arasında dünyanın en büyük dördüncü kütüphanesine sahiptir.

Benzer şekilde Türkiye'de marka üniversite olma yolunda emin adımlarla ilerlemek isteyen Mehmet Akif Ersoy Üniversitesi, markalaşma sürecini başlatarak profesyonel bir biçimde markalaşma adımlarını uygulamaya çalışmıştır. Araştırmadan elde edilen verilere göre durum analizi yaparak markalaşma sürecine başlayan üniversite, ardından güçlü ve zayıf yönlerini analiz etmiştir. Üniversite, hedef kitlesini belirleyerek paydaşlarla iş birliği yapmakta, düzenlenen çalıştaylar ile onların görüş ve önerilerini almaktadır. Kendini Batı Akdeniz Bölümünde küçük bir şehrin can damarında yer alan Mehmet Akif Ersoy Üniversitesi ailesi olarak konumlandıran üniversite, uluslararası mecralarda yer almak istemekte, 'Uluslararas1 Mehmet Akif Ersoy Sempozyumu ve Bilim Sanat Ödülleri Töreni’ gerçekleştirmektedir. Ayrıca Mevlâna, Erasmus, Farabi öğrenci ve öğretim elemanı değişim programı uygulamaktadır. Üniversite, "İstiklalden İstikbale” sloganı ile insanların zihninde yer etme çabasındadır.

Üniversite “'Hayvancılık ve Hayvancılığa Dayalı Sanayiciliğin Geliştirilmesi”, alanında Kalkınma Bakanlığı tarafından desteklenecek 5 pilot üniversiteden biri seçilmiştir. Mehmet Akif Ersoy Üniversitesi yöre ile ilintili olarak hayvancılık, hayvancılığa dayalı sanayi ve özellikle gıda sanayi konusunda konumlandırma çalışmaları yapmaktadır. Ayrıca, Burdur ilinin eğitim ile kendini ön plana çıkarması nedeniyle üniversite; kentin ilim yuvası kimliğini de taşıma gayretindedir.

Mehmet Akif Ersoy Üniversitesi’ nin marka imajı ve marka kişiliğine yönelik çalışmalar yapılması önerilmektedir. Belediye ile iş birliği yoluna gidilerek sosyal imkânların artırılması sağlanmalıdır. Web sitesinde sesli kitaba ulaşılamamıştır. Sitede yer alacak sesli kitaplar engelli öğrencilerin nitelikli eğitim almalarında etkin olacaktır.

Üniversiteyi tanıtıcı film, dergi ve broşürlerin hem Türkçe hem de yabancı dillerde hazırlanması, uluslararası kongre düzenleme çalışmaları için bütçe ayrılması önerilmektedir. Tanıtım faaliyetleri için bütçe ayrılması, üniversitenin radyo ve televizyon imkânlarının artırılması, üniversitenin hedef kitleye erişimini kolaylaştırarak iletişim çabalarına katkı 
Gürbüz, C., Çetinkaya Bozkurt, Ö. \& Dal, N. E.

sağlayacaktır. Dikkat çekici videolar hazırlanarak sosyal medya hesapları üzerinden paylaşılması ile üniversitenin bilinirliğine katkı sağlanabilir.

Akreditasyon çalışmaları Mehmet Akif Ersoy Üniversitesi'nde hedeflendiği oranda gerçekleştirilmektedir (Mehmet Akif Ersoy Üniversitesi, 2016a: Ek A-11). Fakat üniversitenin globalleşme hızını artırması adına eğitim ve marka akreditasyon çalışmaları sayısı arttırılmalıdır.

Sonuç olarak, üniversitelerin markalaşmasına yönelik yapılan araştırmaların kısıtlı olduğu görülmektedir. Üniversiteler bilinirliğini artırmak ve rekabet avantajı sağlamak amacıyla markalaşma çalışmalarına önem vermelidir.

\section{REFERENCES / KAYNAKLAR}

Aaker, D. A. (1996). Building strong brands. New York: Free Press.

Aaker, J. (1997). Dimensions of brand personality. Journal of Marketing Research, 34(3), 347-356.

Ak, T. (2009). Marka yönetimi ve tüketici karar sürecine etkileri (Yayımlanmamış yüksek lisans tezi). Karamanoğlu Mehmet Bey Üniversitesi, Karaman.

Aksoy, T. (2015, 6 Temmuz). Sizin markanızın nasıl bir kişiliği var? Marketing Türkiye dergisi. Erişim Tarihi: 10.10.2017, http://www.marketingturkiye.com.tr/koseyazilari/sizin-markanizin-nasil-bir-kisiligi-var.

Ali-Choudhury, R., Benett, R. \& Savani, S. (2009). University marketing directors views on the components of a university brand. International Review of Public \& Nonprofit Marketing, 6(1), 11-33.

Ar, A. (2002). Marka yaratma stratejileri ve bir uygulama örneği (Yayımlanmamış yüksek lisans tezi). Balıkesir Üniversitesi, Balıkesir.

Aysen, E., Yaylı, A. \& Helvacı, E. (2012). Üniversitelerin marka kişiliği algısının belirlenmesi üzerine bir araştırma. İşletme Araştırmaları Dergisi, 4(4), 182-204.

Bal, H. (2016). Nitel araştırma yöntem ve teknikleri. Bursa: Sentez Yayıncılı.

Balaji, M., Roy, S. K. \& Sadeque, S. (2016). Antecedents and consequences of university brand identification. Journal of Business Research, 69(8), 3023-3032. doi:10.1016/j.jbusres.2016.01.017

Balmer, J. M. (2001). Corporate identity, corporate branding and corporate marketing-seeing through the fog. European Journal of Marketing, 35(3/4), 248-291.

Başer, A. (2008). Hizmet konumlandırılması: Üniversite markalarının konumlandırılmasına yönelik bir çalışma (Yayınlanmamış yüksek lisans tezi). Marmara Üniversitesi, İstanbul.

Borça, G. (2013). Marka ve yönetimi. Eskişehir: Anadolu Üniversitesi Yayınları.

Chapleo, C. (2010). What defines "successful" university brands? International Journal of Public Sector Management, 23(2), 169-183. 
Clark, P., Chapleo, C. \& Suomi, K. (2019). Branding higher education: An exploration of the role of internal branding on middle management in a university rebrand. Tertiary Education and Management, 1-19.

Coşar, M. (2016). Üniversite tercihinde öğrencileri etkileyen faktörler. Eğitim ve Öğretim Araştırmaları Dergisi, $5(1), 1-5$.

Çağlayandereli, M. \& Güleş, H. (2013). Üniversite kenti markasının sosyolojik analizi. (KBAM) Kentsel ve Bölgesel Araştırmalar Ağı 4. Sempozyumu, (Tema: Neo-Liberalizm Sonrası Mekansal Müdahale Biçimleri ve Yansımalar1), 28-30 Kasım 2013 - Mersin, KBAM 4. Sempozyum Bildiri Kitabı, (727-745). Ankara: KBAM.

Çakır, E. (2013). Akademik dünyanın kentsel imgelerinden mitolojik simgelerine üniversite logoları. Millî Folklor, 25(97), 53-69.

Çatı, K., Bilgin, Y. \& Kethüda, Ö. (2016). Türkiye'deki üniversitelerin kendilerini konumlandırdıkları eğitim alanları. Journal of Higher Education \& Science/Yüksekögretim ve Bilim Dergisi, 6(2), 231-241.

Çiçek, H., Demirel, M. \& Onat, O. K. (2010). İşletmelerin web sitelerinin değerlendirilmesine ilişkin bir araştırma. Süleyman Demirel Üniversitesi İktisadi ve İdari Bilimler Fakültesi Dergisi, 15(2), 187-206.

Çifci, S. \& Cop, R. (2007). Marka ve marka yönetimi kavramları: Üniversite öğrencilerinin kot pantolon marka tercihlerine yönelik bir araştırma. Finans Politik \& Ekonomik Yorumlar, 44(512), 69-88.

Demirel, M. (2014). Burdur kent imajı: Mehmet Akif Ersoy Üniversitesi öğrencileri üzerine bir alan araştırması. Mehmet Akif Ersoy Üniversitesi Sosyal Bilimler Enstitüsü Dergisi, 6(10), 230-241.

Ekici, S. (2012). Hizmet sektöründe eğitim kurumlarının markalaşması: Türkiye'deki üniversitelere yönelik bir araştırma (Yüksek Lisans Tezi). İstanbul Ticaret Üniversitesi, İstanbul.

Elo, S. \& Kyngas, H. (2007). The qualitative content analysis process. Journal of Advanced Nursing, 62(1), 107115 .

Ergün, C. (2014). Üniversite ve kent ilişkisi üzerine görüşler: Mehmet Akif Ersoy Üniversitesi örneği. Mehmet Akif Ersoy Üniversitesi Ĕ̆itim Fakültesi Dergisi, 1(31), 216-237.

Gray, B. J., Fam, K. S. \& Lianes, V. A. (2003). Branding universities in Asian markets. Journal of Product \& Brand Management, 12(2), 108-120.

Hassan, S. B., Hamid, M. S. A. \& Bohairy, H. Al. (2010). Perception of destination branding measures: A case study of Alexandria destination marketing organizations. International Journal of Euro-Mediterranean Studies, $3(2), 271-288$.

İslamoğlu, H. (2011). Sosyal bilimlerde araştırma yöntemleri. İstanbul: Beta Yayıncılık.

Judson, K. M., Aurand, T. W., Gorchels, L. \& Gordon, G. L. (2008). Building a university brand from within: University administrators' perspectives of internal branding. Services Marketing Quarterly, 30(1), 54-68.

Keller, K. L. (2013). Strategic brand management. US: Global Edition.

Kotler, P. (2000). Kotler ve pazarlama (A. Özyağcılar, Çev.). İstanbul: Sistem Yayıncılık.

Köksal, Y. \& Sarı, S. (2014). Burdur kent imajının yerel halk ile üniversite öğrencileri arasındaki karşılaştırmalı bir incelemesi. Dumlupınar Üniversitesi Sosyal Bilimler Dergisi, 42, 279-288.

Lockwood, R. C. \& Hadd, J. (2007). Building a brand in higher education. Gallup Management Journal, 12.

Lowry, J. R. \& Owens, B. D. (2001). Developing a positioning strategy for a university. Services Marketing Quarterly, 22(4), 27-42.

Mehmet Akif Ersoy Üniversitesi (2008). Stratejik plan 2008/2012. Erişim Tarihi: 10.10.2017, https://sgdb.mehmetakif.edu.tr/files/20082012StratejikPlan.pdf. 
Mehmet Akif Ersoy Üniversitesi. (2012a). 2012 yılı idare faaliyet raporu. Erişim Tarihi: 10.10.2017, https://sgdb.mehmetakif.edu.tr/files/2012-yili-idare-faaliyet-raporu.pdf.

Mehmet Akif Ersoy Üniversitesi (2012b). Stratejik plan 2013/2017. Erişim Tarihi: 10.10.2017, https://www.mehmetakif.edu.tr/files/20132017StratejikPlan.pdf.

Mehmet Akif Ersoy Üniversitesi. (2013). 2013 y1lı idare faaliyet raporu. Erişim Tarihi: 10.10.2017, https://sgdb.mehmetakif.edu.tr/files/2013-yili-idare-faaliyet-raporu.pdf.

Mehmet Akif Ersoy Üniversitesi. (2014). 2014 yılı idare faaliyet raporu. Erişim Tarihi: 10.10.2017, https://sgdb.mehmetakif.edu.tr/files/2014-yili-idare-faaliyet-raporu.pdf.

Mehmet Akif Ersoy Üniversitesi. (2015). 2015 yılı idare faaliyet raporu. Erişim Tarihi: 10.10.2017, https://sgdb.mehmetakif.edu.tr/files/2015-yili-idare-faaliyet-raporu.pdf.

Mehmet Akif Ersoy Üniversitesi. (2016a). Kurum iç değerlendirme raporu. Erişim Tarihi: 10.10.2017, https://sgdb.mehmetakif.edu.tr/files/2016-yili-Kurum-ic-Degerlendirme-Raporu.pdf.

Mehmet Akif Ersoy Üniversitesi. (2016b). 2016 yılı performans programı. Erişim Tarihi: 10.10.2017, https://sgdb.mehmetakif.edu.tr/files/2016-yili-performans-programi.pdf.

Mehmet Akif Ersoy Üniversitesi. (2016c). 2016 yılı idare faaliyet raporu. Erişim Tarihi: 10.10.2017, https://sgdb.mehmetakif.edu.tr/files/2016-yili-idare-faaliyet-raporu.pdf.

Mehmet Akif Ersoy Üniversitesi. (2016d). Stratejik plan 2017/2021. Erişim Tarihi: 10.10.2017, https://sgdb.mehmetakif.edu.tr/files/2017-2021-Stratejik-Plan.pdf.

Mehmet Akif Ersoy Üniversitesi. (2017a). Genel bilgi. Erişim Tarihi: 10.10.2017, https://mehmetakif.edu.tr/universitemiz-genel-bilgi.

Mehmet Akif Ersoy Üniversitesi. (2017b). Kalite politikamı. Erişim Tarihi: 10.10.2017, https://mehmetakif.edu.tr/universitemiz-kalite-politikamiz.

Mehmet Akif Ersoy Üniversitesi. (2017c). Logo. Erişim Tarihi: 10.10.2017, https://mehmetakif.edu.tr/universitemiz-logo.

Mehmet Akif Ersoy Üniversitesi. (2017d). 2017 yll performans programı. Erişim Tarihi: 10.10.2017, https://sgdb.mehmetakif.edu.tr/files/2017-Yili-Performans-Programi.pdf.

Mehmet Akif Ersoy Üniversitesi. (2017e). Ödemer ile ögrencilerin memnuniyeti artacak. Erişim Tarihi: 10.10.2017, https://mehmetakif.edu.tr/duyuru/5776/odemer-ile-ogrencilerin-memnuniyeti-artacak.

Mehmet Akif Ersoy Üniversitesi. (2017f). Sosyal hizmetler. Erişim Tarihi: 10.10.2017, https://sksdb.mehmetakif.edu.tr/?page=sosyalhizmetler.

Mehmet Akif Ersoy Üniversitesi. (2018a). 2018 yılı idare faaliyet raporu. Erişim Tarihi: 05.02.2020, https://sgdb.mehmetakif.edu.tr/files/2018-yili-idare-faaliyet-raporu.pdf.

Mehmet Akif Ersoy Üniversitesi. (2018b). Kurum iç değerlendirme raporu. Erişim Tarihi: 05.02.2020, https://sgdb.mehmetakif.edu.tr/files/2018-yili-Kurum-ic-Degerlendirme-Raporu.pdf.

Nardalı, S. \& Tanyeri, M. (2011). Yükseköğretimde markalaşma. İşletme Fakültesi Dergisi, 12(2), 309-319.

Okur, M. H. (2007). Yükseköğretim hizmetlerinin pazarlanmasında marka değeri oluşturma ve geliştirme stratejileri: Ankara ilinde örnek bir çalışma (Yayımlanmamış yüksek lisans tezi). Gazi Üniversitesi, Ankara.

Özer, A. (2015). Logo tasarımında marka algısı (Yayımlanmamış yüksek lisans tezi). İstanbul Arel Üniversitesi, İstanbul. 
Sert, G., Kurtoğlu, M., Akıncı, A. \& Seferoğlu, S. (2012). Öğretmenlerin teknoloji kullanma durumlarını inceleyen araştırmalara bir bakış: Bir içerik analizi çalışması. Computers \& Education, 14(46), 1-8.

Şahin, A. (1998). Marka kimliği. İletişim Fakültesi Dergisi, 8, 235-247.

Taş, A. \& Ergin, A. E. (2012). Key factors for student recruitment: The 1ssue of university branding. International Business Research, 5(10), 146-153.

Tayfur, G., Cesur, Z. \& Memiş, S. (2016). Sakarya Üniversitesi’nin marka kişiliğinin belirlenmesine yönelik bir araştırma. International Journal of Social Science, 54, 241-253.

Torlak, M. (2015). Marka şehir oluşturma ve Bursa şehrinin markalaşması için yol haritası. Tüketici ve Tüketim Araştırmaları Dergisi, 7(2), 47-93.

Torlak, Ö. \& Doğan, V. (2011). Üniversite adaylarının üniversite marka algılarının üniversite tercihlerine etkilerinin ölçümü: Eskişehir örneği. İşletme Fakültesi Dergisi, 12(1), 97-113.

Wasmer, D. J., Williams, J. R. \& Stevenson, J. (1997). A reconceptualization of the marketing mix: Using the 4 C's to improve marketing planning in higher education. Journal of Marketing for Higher Education, 8(2), 29-35.

Watkins, B. \& Gonzenbach, W. (2013). Assessing university brand personality through logos: An analysis of the use of academics and athletics in university branding. Journal of Marketing for Higher Education, 23(1), 15-33.

Wæraas, A. \& Solbakk, M. N. (2009). Defining the essence of a university: Lessons from higher education branding. Higher Education, 57(4), 449-462.

Wilkins, S. \& Huisman, J. (2013). Student evaluation of university 1mage attractiveness and it's impact on student attachment to international branch campuses. Journal of Studies in International Education, 17(5), 607-623. doi:10.1177/1028315312472984

Yıldırım, A. \& Şimşek, H. (2006). Sosyal bilimlerde nitel araştırma yöntemleri. Ankara: Seçkin Yayıncılık.

Yıldız, O. (2015). Marka imajı yaratma ve marka yerleştirme stratejileri (Uzmanlık tezi). Türk Patent Enstitüsü, Ankara. 